\title{
Fluoride removal from natural volcanic underground water by an electrocoagulation process: Parametric and cost evaluations
}

\author{
V.F. Mena ${ }^{1}$, A. Betancor-Abreu ${ }^{1}$, S. González ${ }^{1}$, S. Delgado ${ }^{2}$, R.M. Souto ${ }^{1,3}$, J.J. Santana ${ }^{4}$ \\ ${ }^{1}$ Department of Chemistry, Universidad de La Laguna, P.O. Box 456, E-38200 La Laguna \\ (Tenerife), Spain. \\ ${ }^{2}$ Department of Chemical Engineering and Pharmaceutical Technology, Universidad de La \\ Laguna, P.O. Box 456, E-38200 La Laguna (Tenerife), Spain. \\ ${ }^{3}$ Institute of Materials and Nanotechnology, Universidad de La Laguna, P.O. Box 456, E-38200 \\ La Laguna (Tenerife), Spain. \\ ${ }^{4}$ Department of Process Engineering, Universidad de Las Palmas de Gran Canaria, Campus \\ Universitario de Tafira, E-35017 Las Palmas de Gran Canaria (Gran Canaria), Spain.
}




\begin{abstract}
The water supply on the island of Tenerife (Canary Islands, Spain) comes mainly from aquifers of volcanic origin that are notable for the high content of fluorides that make it unviable for human consumption without prior conditioning treatment. The treatments that generate a high rejection of water are not viable, since water is a scarce natural resource of high value. An electrocoagulation process was investigated as a method to treat natural groundwater from volcanic soils containing a dangerously high fluoride content. The operating parameters of an electrocoagulation reactor model with parallel plate aluminum electrodes were optimized for batch and continuous flow operations. In the case of batch operation, it was found that acidification of the water improved fluoride elimination efficiency, with a maximum at $\mathrm{pH}$ 3. Yet, operation at the natural $\mathrm{pH}$ of the water achieved elimination efficiencies between 82 and 92\% depending on the applied current density. An optimum current density of $5 \mathrm{~mA} / \mathrm{cm}^{2}$ was found in terms of the highest removal efficiency, and the kinetics of fluoride removal was adjusted to a pseudo-second-order kinetics. In the continuous-flow operation, with an optimal residence time of $10 \mathrm{~min}$ and a separation of 0.5 $\mathrm{cm}$ between the electrodes, it was observed that the current density that would be applied would depend on the initial concentration of fluoride in the raw water. Then, an initial fluoride concentration of $6.02 \mathrm{mg} / \mathrm{L}$ required a current density $>7.5 \mathrm{~mA} / \mathrm{cm}^{2}$ to comply with the legal guidelines in the product water, while for an initial concentration of $8.98 \mathrm{mg} / \mathrm{L}$, the optimum current density was $10 \mathrm{~mA} / \mathrm{cm}^{2}$. Under these operating conditions, the operating costs will vary between 0.20 and $0.26 € / \mathrm{m}^{3}$ of treated water.
\end{abstract}

Keywords: Water treatment; Electrocoagulation process; Fluoride removal; Aluminum electrodes. 


\section{Introduction}

The threat to human health caused by excessive fluoride intake has been well documented (Kanduti et al., 2016; Ozsvath, 2008). Long-term consumption of water with fluoride concentrations higher than $1.5 \mathrm{mg} / \mathrm{L}$ can cause fluorosis, a disease that affects especially bones and teeth (WHO, 2011). Fluorine can be present in natural groundwater in volcanic areas from two main sources. Firstly, the filtration of surface rain water through rocky material of volcanic origin causes its fluorinated minerals to enter the underground water (D’Alessandro, 2006; Custodio et al., 2016). In addition, zones with underwater volcanic activity have a high concentration of hydrofluoric acid in the gaseous emissions. These, when in contact with water, contribute to the increase in fluoride concentration (D’Alessandro, 2006; Ayoob and Gupta, 2006). As for the Canary Islands, an archipelago of volcanic origin formed by seven major islands (see Figure 1), groundwater is the main natural source of water supply (Custodio et al., 2016). In the northern region of the island of Tenerife, mainly in the La Guancha, Icod de los Vinos and San Juan de la Rambla municipalities, fluoride values above 7 mg/L have been recorded (Hardisson et al., 2001). It is precisely in this geographical area where the main water sources are located, and this water is distributed to a major portion of the island's population. This imposes the need for water treatment to reduce the levels of fluorides to those established by legislation so that they can be used for human consumption (EU Directive, 1998; Real Decreto 140, 2003).

The conditioning of waters with a high fluoride content to comply with the reference values established by regulations can be done in various ways. Table 1 reviews the main procedures for the elimination of fluorides in water described in the scientific literature. They are classified according to the technology employed, and the most relevant characteristics of the processes are

provided. The techniques presenting lower costs are based on absorption/ionic exchange techniques (i.e., those employing ashes, bone and crushed bone as absorbers), although they 
present low fluoride removal efficiencies. In contrast, higher fluoride removals are obtained with techniques that use activated carbon or zeolites, and most especially for methods based on membrane operation like electrodialysis, reverse osmosis and membrane bioreactors (MBRs), although they present the highest operation costs. Extensive research currently focuses on membrane design for improved process performance in order to reduce the high costs related to membrane operation (Krzeminski et al., 2017). Fouling reduction of microbial origin should contribute to longer service lives for MBRs (Sepehri and Sarrafzadeh, 2018), and eventually facilitate their application for fluoride mitigation.

When water losses during the treatment are considered, they amount to approximately 1$2 \%$ for most of the techniques, but can reach $20-30 \%$ in electrodialysis treatments, and $40-60 \%$ for reverse osmosis. Different drawbacks are also associated with the various methods, with turbidity, arsenic content or alkalinity of the samples being the most important. Alternatively, electrocoagulation is a technology employed for the treatment of urban (Chellam and Sari, 2016; Tian et al., 2016) and industrial wastewaters (Hu et al., 2008; Ahmed et al., 2012; Drouiche et al., 2012; Khandegar and Saroha, 2013; Khaled et al., 2014; Aoudj et al., 2015; Palahouane et al., 2015), although some reports have also explored this technique for conditioning of water for human consumption (Bennajah et al., 2009; Almazán-García et al., 2012; Battula et al., 2014; Dubrawski et al., 2014; Govindan et al., 2015), particularly with regard to fluoride or arsenic elimination. In comparison with the techniques listed in Table 1, this procedure exhibits high fluoride removal efficiencies, easy operation at a relative cost, and the feasibility of using a completely automated system (Rajeshwar et al., 1994; Chen, 2014; Mollah at el., 2004; Emamjomeh and Sivakumar, 2009).

Electrocoagulation is a process in which the destabilization of colloids occurs due to the application of an electric field between the electrodes of an electrolytic cell (coagulation by 
polarization), or due to the action of coagulating agents resulting from the oxidation of an anode. The simplest electrolytic cell consists of two electrodes, an anode, where oxidation of the metal occurs, and a cathode, where the reduction of a series of electrolyte components occurs. The ionic species produced in the electrodes destabilize the charges of the contaminating particles present in the water. When these charges have been balanced, the physical-chemical processes that keep the particles in suspension disappear, thus allowing the formation of aggregates, and initiating the coagulation process. Hydrolysis, electrolysis, ionization and formation of free radicals are the important reactions that pollutants may undergo at this stage (Hakizimana et al., 2017).

It is accepted that three stages are involved in the electrocoagulation process: formation of the coagulant by oxidation of the metal at the anode, destabilization of the contaminants and emulsions and, finally, formation of flocs by aggregation of contaminant particles or adsorption of the contaminant in the coagulant. The most influential factors determining and controlling the reactions in the system and the formation of the coagulant are: the nature and concentration of the contaminants (Zhu et al., 2007), pH (Sivakumar and Emamjomeh, 2005; Emamjomeh and Sivakumar, 2006), distance between electrodes (Emamjomeh and Sivakumar, 2006), and applied charge density (Emamjomeh and Sivakumar, 2006). For fluoride removal, aluminum is the only metal used as an anode, whereas both aluminum and iron can be used for the cathode, the latter often being employed to reduce costs (Khandegar and Saroha, 2013). Although several electrocoagulation reactor configurations have been proposed for fluoride removal (i.e., filter-press type reactors, ascending flow reactors, circular or rectangular base, batch type, continuous flow, etc.), they have always been reactors at the scale of laboratory. To our knowledge, the only electrocoagulation reactor in operation was described by Andey and coworkers, where water treatment plants for human consumption, fed by solar panels, were installed to supply treated water to small populations in India (Andey et al., 2013). 
In this work, we have evaluated and optimized the operation of an electrocoagulation reactor using aluminum electrodes for the removal of fluorides from groundwater of volcanic origin in the north of the island of Tenerife. The technical feasibility of the proposed system has been verified at the laboratory level, and the operational parameters in the reactor have been determined and optimized. Experiments have been designed and conducted with natural gallery water with a high concentration of fluorides, monitoring the final quality of the treated water and operating costs.

\section{Experimental procedure}

The electrocoagulation process was performed in a container of 2 liters capacity, with dimensions $5.5 \mathrm{~cm} \times 15 \mathrm{~cm} \times 24.25 \mathrm{~cm}$. The physical and hydrodynamic design of the reactor was optimized in a previous work (Mena et al., submitted). An immersion pump was placed inside the reactor, which allowed the appropriate agitation of the liquid phase to be adjusted during the entire test. The electrode assembly consisted of 14 aluminum plates of $5 \mathrm{~cm} \times 12 \mathrm{~cm}$ size, with $5 \mathrm{~mm}$ separation between them. The electrodes were alternately arranged for connection to the power supply unit as shown in Figure 2. Prior to their assembly inside the electrocoagulation reactor, the aluminum plates were subjected to a cleaning and conditioning process according to ASTM G103(2017)e1, and then they were stored in sealed plastic bags until use.

Current supply and voltage monitoring in the reactor was accomplished using an QPX1200SP voltage source (Aim-TTI, Huntingdon, United Kingdom). Either a maximum output voltage of $60 \mathrm{~V}$ or a maximum current of output of $50 \mathrm{~A}$ could be applied, both values subject to a maximum power of $1200 \mathrm{~W}$. The entire device is controlled through a PIPO computer equipped 
with Windows ${ }^{\circledR}$ and its own control software interface. The effect of operation parameters on the electrocoagulation process was investigated for the ranges listed in Table 2.

Electrocoagulation tests were performed with underground water from the Barranco de Vergara Gallery located in La Guancha, Tenerife (see Figure 1). The water was collected for transportation to the laboratory without any pretreatment. The average chemical composition of the raw water is shown in Table 3. For all water collections, fluoride concentration and $\mathrm{pH}$ values were monitored prior to and at different stages of the electrocoagulation operation by potentiometry (Metrohm, Herisau, Switzerland). Fluoride analysis were performed using a fluoride ion-selective electrode connected to an $827 \mathrm{pH}$ lab instrument equipped with an $\mathrm{Ag} / \mathrm{AgCl} / \mathrm{KCl}$ (saturated) reference electrode, whereas a $691 \mathrm{pH}-$ Meter with an Aquatrode Plus combined $\mathrm{pH}$ electrode was employed for $\mathrm{pH}$ monitoring. A buffer solution of $\mathrm{pH} 5.5$ was added to the water samples to avoid interference from any other ions on the ion-selective fluoride electrode. The system was calibrated using standard solutions of fluoride ion concentrations 0.5 $15 \mathrm{mg} / \mathrm{L}$.

To evaluate the loss of $\mathrm{Al}$ at the anode, the electrode was weighed before and after electrocoagulation tests.

\section{Results and discussion}

The optimization of the reactor and its subsequent validation to use this technique for treating natural spring waters of volcanic origin was addressed in a previous work (Mena et al., submitted). In that work, the evolution of the mechanical design of the reactor using aluminum electrodes was explained in detail. We started with a reactor of $145 \mathrm{~mL}$ capacity, formed by a system of two electrodes, which evolved into a reactor of $368 \mathrm{~mL}$ capacity containing a set of 4

electrodes (two anodes and two cathodes). Finally, we proceeded to the introduction of a set of 
multi-electrodes, increasing the volume of the reactor to $2000 \mathrm{~mL}$, this being the optimum cell design employed for the tests carried out in the present work. The configuration of this reactor consisted of a system of 14 aluminum electrodes separated $5 \mathrm{~mm}$ as shown in Figure 2.

Several tests have been carried out in order to ascertain the influence of the current density, the $\mathrm{pH}$, the duration of polarity change to the electrodes (half-period), and the residence time of the sample in the reactor on the EC process. These tests were carried out in batch regime and under steady state operation. Table 2 shows the ranges of variability of the parameters controlled and modified in the different optimization tests. These parameters have been chosen due to their relevance in the process of fluoride removal using the electrocoagulation technique.

\subsection{Batch tests}

\subsubsection{Influence of the time of operation}

The reactor has been tested in four different operating times, namely 5, 8, 10 and 30 min. Table 4 shows the results obtained in the tests, while Figure 3 shows the experimental relationships found between the three parameters considered in this study. The percentage of fluoride removal was calculated using equation (1):

$$
\operatorname{Removal}(\%)=\frac{\left[\mathrm{F}^{-}\right]_{\mathrm{i}}-\left[\mathrm{F}^{-}\right]_{\mathrm{f}}}{\left[\mathrm{F}^{-}\right]_{\mathrm{i}}} \cdot 100
$$

where $\left[\mathrm{F}^{-}\right]_{\mathrm{i}}$ and $\left[\mathrm{F}^{-}\right]_{\mathrm{f}}$ are the initial and final concentration of fluorides in solution, respectively.

When considering small operating times, a progressive decrease in the concentration of fluorides was observed. Thus, with 5 min of operation, fluoride removal efficiencies greater than $68 \%$ were achieved, which increased up to $72 \%$ with $8 \mathrm{~min}$, up to $78 \%$ with $10 \mathrm{~min}$ and, finally, up to almost $85 \%$ for operation times of $30 \mathrm{~min}$. It is important to note that obtaining final 
concentrations of fluorides within the established legal limits was only achieved for operation times longer than 30 min, although this was not the objective for the tests at this stage. In all cases there was an increase in the voltage drop of the system and a negligible $\mathrm{pH}$ change.

A preliminary economic evaluation was performed by taking into account the cost of the electrode materials and the consumed electricity. The equation used for this cost estimation is:

$$
\text { Operation Cost }=a \cdot E C_{\text {Electrode }}+b \cdot E C_{\text {Energy }}
$$

where $E C_{\text {Electrode }}$ is expressed as ( $\mathrm{kg} \mathrm{Al} \mathrm{lost)} / \mathrm{m}^{3}$, and $E C_{\text {Energy }}$ as $\mathrm{kWh} / \mathrm{m}^{3}$ of treated water for the elimination of fluorides. The parametric constants $a$ and $b$ were introduced to relate the costs to the Spanish market in 2018, and amounted to $1.720 € /(\mathrm{kg} \mathrm{Al})$ and $0.117 € / \mathrm{kWh}$, respectively. Analogously, the following equation was used to calculate the energy consumption:

$$
\text { Energy consumption }\left(\frac{\mathrm{kWh}}{\mathrm{m}^{3}}\right)=\frac{\text { voltage } \cdot \text { current } \cdot \text { runtime }}{\text { working volume of reactor }}
$$

Accordingly, it was found that the operating costs in the electrocoagulation operation show a power-law increase with respect to the treatment time (see Figure 3A). A cost of $0.175 € / \mathrm{m}^{3}$ was determined for the water treated during 5 min, which increased to $0.278,0.330$ and $0.531 € / \mathrm{m}^{3}$ when the operating times were 8,10 and 30 min, respectively. A similar trend was observed between the increase in the percentage of fluoride removal and the treatment time (cf. Figure 3A). On the other hand, the dependence between operating costs and the percentage of fluoride removal is linear, as can be seen in Figure 3B. This shows that for every $1 \%$ that increases the elimination of fluorides, there is an approximate increase of 2 cents per cubic meter of water treated under the conditions tested. 


\subsubsection{Influence of initial $p H$}

A major factor influencing the elimination of fluorides in the electrocoagulation operation is the $\mathrm{pH}$ of the raw water. It has been reported that the $\mathrm{pH}$ of the solution can increase or decrease due to the reactions involved in the process, and that the direction of the $\mathrm{pH}$ change depends directly on the initial $\mathrm{pH}$ of the raw water, so that a final $\mathrm{pH}$ is reached within the range of 8-9.5 (Thakur and Mondal, 2017). Other studies have shown that the $\mathrm{pH}$ variation of the solution is smaller as the $\mathrm{pH}$ in the solution to be treated increases (Chen et al., 2000; Gürses et al., 2002; Kobya et al., 2006; Kobya et al., 2003). Therefore, to determine the influence of $\mathrm{pH}$ on the electrocoagulation operation, it is necessary to take into account the processes involved.

To understand the effect that $\mathrm{pH}$ exerts on the electrocoagulation process, we must take into account the processes involved. Equation (4) describes the dissolution process of aluminum at the anode, while the reaction (8) defines the reduction process that takes place at the cathode with the release of hydrogen gas and hydroxyl ions, which are responsible for the alkalization of the medium (Kobya et al., 2011). The dissolved aluminum present in solution precipitates in the form of aluminum hydroxide as shown in equation (6), although this process is greatly influenced by the $\mathrm{pH}$.

Reaction at the anode: $\quad \mathrm{Al} \rightarrow \mathrm{Al}^{3+}+3 \mathrm{e}^{-}$

Reaction at the cathode: $\quad 3 \mathrm{H}_{2} \mathrm{O}+3 \mathrm{e}^{-} \rightarrow \frac{3}{2} \mathrm{H}_{2}+3 \mathrm{OH}^{-}$

Reaction in solution: $\quad \mathrm{Al}^{3+}+3 \mathrm{OH}^{-} \leftrightarrow \mathrm{Al}(\mathrm{OH})_{3}$

Although the scientific community has not yet ascertained the exact mechanism for the process of fluoride removal by aluminum (Zhu et al., 2007), two alternative mechanisms are currently considered the most likely. They propose the elimination of fluoride by co-precipitation, as indicated in equation (7), or the removal of fluoride by adsorption given by equation (8): 


$$
\begin{aligned}
& \mathrm{Al}_{\mathrm{n}}(\mathrm{OH})_{3 \mathrm{n}}+\mathrm{mF}^{-} \rightarrow \mathrm{Al}_{\mathrm{n}} \mathrm{F}_{\mathrm{m}}(\mathrm{OH})_{(3 \mathrm{n}-\mathrm{m})}+\mathrm{mOH}^{-} \\
& \mathrm{nAl}^{3+}+(3 \mathrm{n}-\mathrm{m}) \mathrm{OH}^{-}+\mathrm{mF}^{-} \rightarrow \mathrm{Al}_{\mathrm{n}} \mathrm{F}_{\mathrm{m}}(\mathrm{OH})_{(3 \mathrm{n}-\mathrm{m})}
\end{aligned}
$$

In order to evaluate the influence on the electrocoagulation process due to the initial $\mathrm{pH}$ in the natural water, discontinuous batch tests were performed with an operating time of 30 minutes. In these experiments, the initial $\mathrm{pH}$ was varied between 1 and 11 with intervals of $2 \mathrm{pH}$ units. Table 5 and Figure 4 summarize the results obtained. In general, the $\mathrm{pH}$ of the medium was always observed to shift to more alkaline values in all cases, although its relative extent greatly varied from one case to another. Thus, an increase of about $65 \%$ was observed in the case of $\mathrm{pH} 1$, reaching a final value of $\mathrm{pH}$ 1.72. It can be noticed that the $\mathrm{pH}$ change follows an almost linear dependence with the elapse of time $\left(R^{2}=0.94\right)$, and no formation of deposits is observed at the bottom of the reactor. For initial $\mathrm{pH}$ values 3 and 5 , final $\mathrm{pH}$ values close to 5 were produced, while basic $\mathrm{pH}$ values were obtained for the rest of the conditions considered. In all these cases, the formation of precipitates inside the reactor was observed, which increased in amount as the $\mathrm{pH}$ of the solution increased.

Regarding the percentage of fluoride elimination, it was greater than $90 \%$ in the solutions with neutral or acidic $\mathrm{pH}$ values, and the maximum removal of fluorides was observed for water at $\mathrm{pH}$ 3. By contrast, the removal efficiency steadily decreased as the medium became more alkaline. For example, although a rather high removal percentage of $82.44 \%$ was still observed for the water with an initial $\mathrm{pH}$ of 9.02 , the efficiency dropped abruptly to $56.80 \%$ for $\mathrm{pH} 11$. This feature can be explained by considering the different fluoride and aluminum ion species present in the solution as a function of $\mathrm{pH}$. In summary, the $\mathrm{pH}$-dependent polymerization reactions that can take place are the following (Rebhun and Lurie, 1993): 


$$
\begin{gathered}
{\left[\mathrm{Al}\left(\mathrm{H}_{2} \mathrm{O}\right)_{6}\right]_{(a q)}^{3+} \rightarrow\left[\mathrm{Al}\left(\mathrm{H}_{2} \mathrm{O}\right)_{5} \mathrm{OH}\right]_{(a q)}^{2+} \frac{\mathrm{OH}}{\text { Polymerization }}\left[\mathrm{Al}_{6}\left(\mathrm{H}_{2} \mathrm{O}\right)_{15}\right]_{(a q)}^{3+}} \\
{\left[\mathrm{Al}(\mathrm{OH})_{4}\right]^{-} \underset{\text { Alkaline } \mathrm{pH}}{\stackrel{\mathrm{OH}}{\mathrm{OH}}}\left[\mathrm{Al}(\mathrm{OH})_{3}\left(\mathrm{H}_{2} \mathrm{O}\right)_{3}\right]_{(s)} \leftarrow\left[\mathrm{Al}_{8}\left(\mathrm{H}_{2} \mathrm{O}\right)_{20}\right]_{(a q)}^{4+} \downarrow_{\mathrm{pH} 4 \text { to } ~}}
\end{gathered}
$$

The $\mathrm{pH}$ range for the precipitation of aluminum hydroxide occurs between approximately 4 and 13. It is in this range where the positively charged aluminum complex polyhydroxides that act effectively as coagulants are formed. These charged species can be transformed into $\mathrm{Al}(\mathrm{OH})_{3}(\mathrm{~s})$ (Behbahani et al., 2011), a compound with low solubility, which is finally polymerized as $\mathrm{Al}_{\mathrm{n}}(\mathrm{OH})_{3 \mathrm{n}}$, giving rise to the formation of dense flocs. Therefore, the elimination of fluorides will be dominated, among other factors, by an electrostatic attractive interaction, which is directly influenced by the $\mathrm{pH}$ of the environment. At $\mathrm{pH} 3$, the maximum fluoride removal is obtained, confirming that electrostatic attraction prevails at this acidic $\mathrm{pH}$ value. As the $\mathrm{pH}$ increases, the positive charge of the colloidal particles of $\mathrm{Al}(\mathrm{OH})_{3}$ is reduced, and such decrease is more abrupt at $\mathrm{pH}$ values above 9 due to the formation of $\mathrm{Al}(\mathrm{OH})_{4}^{-}$.

Finally, operating costs increase as the initial $\mathrm{pH}$ value increases. It is observed that for $\mathrm{pH}$ conditions between 7 and 9, which is the natural $\mathrm{pH}$ range of the treated water, the operating costs fluctuate around the same value, namely $0.40 € / \mathrm{m}^{3}$ of treated water. Although the operating costs obtained in the range of $\mathrm{pH} 1-5$ are apparently lower, it must be taken in account that cost estimation was only based on the energy consumption and the cost of the aluminum consumed, whereas the costs associated with the regulation of $\mathrm{pH}$ were not considered at this stage.

\subsubsection{Influence of the current density}

The formation and evolution of the flocs is directly related to the current density applied in the reactor. According to Faraday's law, the increase in the current that flows between the electrodes will lead to a greater production of coagulant in the process. Figure 5 shows the 
evolution of the fluoride removal percentage, as well as the operating costs and $\mathrm{pH}$, when the current density was varied in the interval extending between $3-15 \mathrm{~mA} / \mathrm{cm}^{2}$. In general, the percentage of fluoride removal increased with the applied current density, reaching a maximum of around $80 \%$ elimination. For current densities greater than $3 \mathrm{~mA} / \mathrm{cm}^{2}$, values close to $80 \%$ elimination are already obtained, while the associated operating costs increase linearly with the current density $\left(R^{2}=0.9801\right)$. By considering only the influence of the current density, and thus failing to assess other variables that may be involved in the elimination of fluorides and the cost of operation, an optimum condition could be set between 5 and $10 \mathrm{~mA} / \mathrm{cm}^{2}$.

\subsubsection{Influence of voltage reversal}

In order to minimize the formation of scales on the surface of the aluminum electrodes accompanying the metal dissolution reaction, the system was tested by applying direct current, although periodically alternating the polarity of the electrodes. In this way, half-periods of polarity are applied on the electrodes effectively alternating the cathode and the anode in the electrochemical cell. The working half-periods considered in this investigation were 30, 60 and 120 s. Figure 6 summarizes the results obtained by changing the duration of the polarization halfperiod. It is clearly observed how the half-period has a greater effect on the operating costs than on the efficiency of fluoride removal. Thus, the fluoride removal percentage increased as the halfperiod increased, although with very modest increments ranging from $76.63 \%$ for a half-period of 30 s to $78.75 \%$ for a half-period of 120 s (i.e., an increase of approximately $2.8 \%$ ). By contrast, the operation costs decreased for a half-period of $60 \mathrm{~s}$, which seems to indicate that with this frequency of alternating cathode/anode there was lesser blockage of the electrode surface by scaling and therefore effectively favoring the dissolution of aluminum. 


\subsubsection{Kinetic characterization}

The main objective of the kinetic characterization was to establish the reaction order in the process. Although the reactions involved in the electrocoagulation process using aluminum electrodes are complex, and they are controlled by multiple variables that may affect each other, some information can be gathered from the tests described in the previous sections. Therefore, it has been considered that the process can be described by a pseudo-kinetic model where the reaction rate is described by a mechanism of the n-th order as proposed by Thakur and Mondal (Thakur and Mondal, 2017):

$$
\frac{d C}{d t}=-k \cdot C^{n}
$$

where $C$ is the fluoride concentration, $k$ is the kinetic constant, $n$ is the reaction order, and $t$ is the reaction time. Considering kinetics of pseudo-first and pseudo-second order, the integration of equation (9) leads to:

Pseudo-first-order: $\quad \ln \left(\frac{C_{t}}{C_{i}}\right)=-k_{1} \cdot t$

Pseudo-second-order: $\quad \frac{1}{C_{t}}-\frac{1}{C_{i}}=k_{2} \cdot t$

and the kinetic constant is determined from the value of the slope of the linear fit for each model. In this study, we have evaluated the degree of adjustment of our data considering the sample of untreated water and, subsequently, evaluating the effects caused varying both the initial $\mathrm{pH}$ and the applied current density. Table 6 summarizes the results obtained using this procedure, whereas Figure 7 depicts the plots containing the fitted data to the models. When analyzing the kinetics treating the raw water, it is observed that even for a test time of $30 \mathrm{~min}$. the data obtained are 
adjusted with a similar degree of accuracy to both kinetic models, with a slight emphasis on the second order pseudo-kinetic model.

In experiments varying the initial $\mathrm{pH}$ of the solution and fitting the kinetics described by equations (10) and (11), it is observed that both models satisfactorily fit the experimental data, regardless of the $\mathrm{pH}$, with the exception of $\mathrm{pH} 11$. In this case, significant deviations between the simulated and experimental data are observed for both models, namely $R^{2}=0.5706$ for the pseudofirst-order kinetics and $R^{2}=0.6255$ for the pseudo-second-order kinetics. This feature may be due to the interference produced by the formation of $\mathrm{Al}(\mathrm{OH}) 4^{-}$on the adsorption and attraction of fluoride ions to the alumina flocs.

Likewise, the kinetics of the EC process were evaluated with regards to the variation of the applied current density. It was observed that the fits to the proposed models got worse for a current density of $10 \mathrm{~mA} / \mathrm{cm}^{2}$, whereas they improved for greater current densities.

\subsection{Continuous flow regime}

Based on the results previously obtained considering a discontinuous regime, the EC process was carried out under continuous flow cell conditions to evaluate the behavior of the system under operating conditions close to those expected in either pilot or real scales. Therefore, it should account for any seasonal variation in the minimum and maximum fluoride concentration of the natural underground water. Accordingly, the residence time of the water to be treated inside the reactor was optimized, as well as the effect that the applied current density has on the efficiency of fluoride removal and the cost of operation. 


\subsubsection{Influence of residence time}

The residence time was set to 5, 8, 10 and 15 min by varying the water flow at the entrance of the electrochemical reactor, and the percentage of fluoride removal, $\mathrm{pH}$ variation and the operating costs of the process were analyzed as shown in Figure 8. It was found that the operating costs increased with increasing residence time. Thus, for an increase in the residence time of 5 to 15 min, the operating cost increased by approximately 203\%. The percentage of elimination of fluorides also increased with increased residence time, leading to a maximum percentage of elimination of $85 \%$ for a residence time of 15 min, with almost no variation in the $\mathrm{pH}$ of the medium.

On the other hand, the variation of operating costs with the residence time followed a linear trend with a fit quality of $R^{2}=0.9946$, finding that the operating cost increased $0.035 €$ for each minute that residence time increases.

\subsubsection{Influence of the current density during long-duration tests}

The current density exerts a determining effect on the amount of fluoride removed given the electrochemical nature of the process. From what was observed in the previous tests, the applied current density will depend, for a fixed residence time, on the initial concentration of fluoride present in the raw water. Based on the results obtained in the previous section, a residence time of 10 min was established and the effect of current density was analyzed when treating two raw waters presenting the minimum and maximum fluoride concentrations recorded throughout the study period. The aim was to observe the effect of the variation in the fluoride concentration and $\mathrm{pH}$ of a real sample due to variations in the quality of the raw water due to seasonal effects. The first sample had an initial fluoride concentration of $6.02 \mathrm{mg} / \mathrm{L}$ and a $\mathrm{pH}$ of 8.41 , while the second sample had an initial fluoride concentration of $8.98 \mathrm{mg} / \mathrm{L}$ and $\mathrm{pH}$ 7.16. 


\subsubsection{Raw water with fluoride concentration of $6.02 \mathrm{mg} / \mathrm{L}$.}

Figure 9A-B show the evolution of the fluoride concentration and the percentage of fluoride removal over time for a 24-h test by applying to the system current densities of 5, 7.5 and 10 $\mathrm{mA} / \mathrm{cm}^{2}$. For the three current densities, a drastic decrease in the concentration of fluorides was observed in the first minutes of operation. Thus, there was a reduction in the concentration of fluorides greater than $64 \%$ in the first $10 \mathrm{~min}$, increasing to $72.8 \%$ at $24 \mathrm{~h}$, which was recorded for a current density of $5 \mathrm{~mA} / \mathrm{cm}^{2}$ : an operating condition that exhibited the poorest removal efficiencies at all times. Even then, this removal rate corresponds to a final fluoride concentration of $1.64 \mathrm{mg} / \mathrm{L}$. In general, it was observed that fluoride reduction occurred significantly during the first $20 \mathrm{~min}$ of testing, with values of $1.67 \mathrm{mg} / \mathrm{L}$ that would vary very little throughout the remaining duration of the test, with an average of $1.66 \mathrm{mg} / \mathrm{L}$. Next, for a current density of 7.5 $\mathrm{mA} / \mathrm{cm}^{2}$, the elimination rate increased to $74.4 \%$ in the first $10 \mathrm{~min}$, then stabilizing at $78.4 \%$ after $24 \mathrm{~h}$. The corresponding fluoride concentrations were $1.34 \mathrm{mg} / \mathrm{L}$ at $20 \mathrm{~min}$, and $1.30 \mathrm{mg} / \mathrm{L}$ at the end of the test. On average, the composition throughout the complete test was $1.30 \mathrm{mg} / \mathrm{L}$, thus always below the maximum legal requirement. Furthermore, for a current density of $10 \mathrm{~mA} / \mathrm{cm}^{2}$, a similar trend was observed as in the previous two cases, resulting in a final fluoride concentration of $1.13 \mathrm{mg} / \mathrm{L}$, which represents an elimination percentage of $81.2 \%$, and with an average of 1.09 $\mathrm{mg} / \mathrm{L}$ that was already reached after 20 min operation. In addition, a linear dependence was found between the percentage of fluoride removed and the current density applied. Thus, for each $\mathrm{mA} / \mathrm{cm}^{2}$ increase in current density, the percentage of fluoride removal increases by $1.7 \%$. In these cases, the energy consumption is of an order of similar magnitude, $1.7 \mathrm{kWh} / \mathrm{m}^{3}$ for current density $7.5 \mathrm{~mA} / \mathrm{cm}^{2}$ and $1.9 \mathrm{kWh} / \mathrm{m}^{3}$ for current densities of $10 \mathrm{~mA} / \mathrm{cm}^{2}$. The operating costs varied within a very small range, namely between 0.20 and $0.22 € / \mathrm{m}^{3}$ of treated water. 
In all cases there was alkalization of the medium over time and with the increase of the applied current density. Thus, a final pH of 8.9 occurred at $24 \mathrm{~h}$ for a current density of $5 \mathrm{~mA} / \mathrm{cm}^{2}$, whereas the $\mathrm{pH}$ increased to 9.1 and 9.65 for current densities of 7.5 and $10 \mathrm{~mA} / \mathrm{cm}^{2}$, respectively. A visual inspection of the aluminum electrodes evidenced increased scale formation on the surface of the electrodes, which may account for a decrease in the percentage of fluoride reduction in the water. These incrustations reduce the electrode/solution contact area, which, for long periods of work, can result in a loss of fluoride removal performance or in the need to increase the energy supplied to the system.

\subsubsection{Raw water with fluoride concentration of $8.98 \mathrm{mg} / \mathrm{L}$.}

In the case of raw water with an initial fluoride concentration of $8.98 \mathrm{mg} / \mathrm{L}$, it was observed that when applying current densities of 5 and $7.5 \mathrm{~mA} / \mathrm{cm}^{2}$, the final concentration of fluoride after $24 \mathrm{~h}$ of operation decreased to 2.25 and $1.91 \mathrm{mg} / \mathrm{L}$ respectively, values higher than the maximum allowed by current legislation. Increasing the current density to $10 \mathrm{~mA} / \mathrm{cm}^{2}$ resulted in a decrease in the fluoride concentration to $1.42 \mathrm{mg} / \mathrm{L}$ after $20 \mathrm{~min}$ of operation, further varying between1.24 - $1.46 \mathrm{mg} / \mathrm{L}$ until completing the 24-hour test, and obtaining a final fluoride concentration of 1.43 $\mathrm{mg} / \mathrm{L}$ after $24 \mathrm{~h}$ with a measurement of $1.38 \mathrm{mg} / \mathrm{L}$. Figure 10 shows the evolution of fluoride concentration as function of $\mathrm{pH}$ and percentage of fluoride removal over time. Alkalization of the medium was observed as well, since the $\mathrm{pH}$ increased from an initial value of 7.11 to a final value of around 8.5. Regarding the operating costs, it was found that, for a work regime of $24 \mathrm{~h}$, the associated cost was $0.261 € / \mathrm{m}^{3}$ of treated water.

Bearing in mind that the main objective of this study focused on the treatment of underground water to be used in water supply networks for human consumption, it is expected that it must comply with the most restrictive regulations that exist at present in Spain (Real Decreto 
140, 2003). For the sake of comparative purposes, Table 7 shows the maximum legal allowances established for the main parameters of water, as well as those obtained in the 24-h continuous tests performed using current densities that allowed fluoride concentrations to be obtained below the established legal limits. It is readily observable that both the $\mathrm{pH}$ and the concentration of fluoride in the product water fully complied with the allowed ranges for these parameters during the tests. Furthermore, when raw waters were tested with a variability in the concentration of fluorides and $\mathrm{pH}$ around the limit values listed in Table 3, it implied that the applied current density had to be adjusted according to the initial concentration of fluorides. In any case, operating costs did not substantially increase during such operation.

Finally, in comparison with the operating cost of reverse osmosis, which ranges between 0.56-0.63 $€ / \mathrm{m}^{3}$ of treated water for processes up to $140,000 \mathrm{~m}^{3} /$ day, as in our case (Martínez, 2002), electrocoagulation seems to be a more economical process for water pretreatment. Moreover, when compared with electrodialysis, which presents treatment costs between 0.35-0.45 $€ / \mathrm{m}^{3}$ of treated water (Martínez, 2002), although the costs are similar, the electrocoagulation process does not present water flow losses, which means it can be implemented as pretreatment of groundwater prior to a post-treatment by electrodialysis.

\section{Conclusions}

Electrocoagulation is presented here as an efficient method to remove fluorides from groundwater of volcanic origin. The operating conditions have been optimized both in batch and continuous-flow operation regimes for a $2 \mathrm{~L}$ capacity reactor composed of 14 aluminum electrodes of dimensions $5 \mathrm{~cm} \times 12 \mathrm{~cm}$, with $5 \mathrm{~mm}$ separation between them. 
The use of the EC technique for the treatment of the natural waters was validated through the tests conducted in batch regime. Regarding the natural $\mathrm{pH}$ of the water, it was found that prior acidification of the water improved the efficiency of fluoride removal, with an optimum condition for $\mathrm{pH}$ 3. In this case, a fluoride removal up to $93.91 \%$ was attained leading to a fluoride concentration of $0.43 \mathrm{mg} / \mathrm{L}$ in the product water and with an operating cost of $0.318 € / \mathrm{m}^{3}$ of treated water The percentage of fluoride removal varied between 68.9 and $84.7 \%$ for operating times ranging from 5 to $30 \mathrm{~min}$. As for the current density, an optimum was found for $5 \mathrm{~mA} / \mathrm{cm}^{2}$ based on the percentage of fluoride removal.

The kinetics of fluoride removal conforms to a pseudo-second order law when investigating the influence of both the initial $\mathrm{pH}$ and the applied current density.

The optimal operating conditions found for the continuous-flow operation of natural water without prior conditioning were established by considering the initial concentration of fluoride. Thus, for the range of variability of the fluoride concentration found during the analysis period, the optimal current densities range between 7.5 and $10 \mathrm{~mA} / \mathrm{cm}^{2}$ for waters with fluoride concentrations ranging between 6 and $9 \mathrm{mg} / \mathrm{L}$, setting a residence time of $10 \mathrm{~min}$. The final concentration of fluoride obtained for each case is below the established legal limit of $1.5 \mathrm{mg} / \mathrm{L}$, with operating costs of around $0.2-0.26 € / \mathrm{m}^{3}$ of treated water.

\section{Acknowledgements}

Financial support by the Comunidad de Aguas Barranco de Vergara (Los Realejos, Spain) under research contract "Estudio de la aplicación de la tecnología de electrocoagulación en la separación de fluoruros en aguas subterráneas” is gratefully acknowledged. V.F.M. is grateful to Universidad de La Laguna and Obra Social “La Caixa” for a research contract. 


\section{References}

Ahmed, M.T., Chaabane, T., Maachi, R., Darchen, A., 2012. Efficiency of a pretreatment by electrocoagulation with aluminum electrodes in a nanofiltration treatment of polluted water. Procedia Eng. 33, 465-474. https://doi.org/10.1016/j.proeng.2012.01.1226.

Almazán-García, F., Rivera-Huerta, M.M., Martín-Domínguez, A., 2012. Comparación entre la coagulación convencional y la electrocoagulación en la remoción de fluoruros de agua para consumo humano. Tecnol. Ciencia Ed. 27, 101-110.

Andey, S., Labhasetwar, P.K., Khadse, G., Gwala, P., Pal, P., Deshmukh, P., 2013. Performance evaluation of solar power based electrolytic defluoridation plants in India. Int. J. Water Resources Arid Environ. 2, 139-145.

Aoudj, S., Khelifa, A., Drouiche, N., Belkada, R., Miroud, D., 2015. Simultaneous removal of chromium(VI) and fluoride by electrocoagulation-electroflotation: Application of a hybrid Fe-Al anode. Chem. Eng. J. 267, 153-162. https://doi.org/10.1016/j.cej.2014.12.081.

Ayoob, S., Gupta, A.K., 2006. Fluoride in drinking water: A Review on the status and stress effects. Crit. Rev. Env. Sci. Tec. 36, 433-487. https://doi.org/10.1080/10643380600678112.

Ayoob, S., Gupta, A.K., Bhat, V.T., 2008. A conceptual overview on sustainable technologies for the defluoridation of drinking water. Crit. Rev. Environ. Sci. Technol. 38, 401-470. https://doi.org/10.1080/10643380701413310.

Battula, S.K., Cheukuri, J., Raman, N.V.V.S.S., Himabindu, V., Bhagawan, D., 2014. Effective removal of fluoride from ground water using electro-coagulation. Int. J. Eng. Res. Appl. 4, 439445.

Behbahani, M., Moghaddam, M.R.A., Arami, M., 2011. Techno-economical evaluation of fluoride removal by electrocoagulation process: optimization through response surface methodology. Desalination 271, 209-218. https://doi.org/10.1016/j.desal.2010.12.033.

Bennajah, M., Gourich, B., Essadki, A.H., Vial, C., Delmas, H., 2009. Defluoridation of Morocco drinking water by electrocoagulation/electroflottation in an electrochemical external-loop airlift reactor. Chem. Eng. J. 148, 122-131. https://doi.org/10.1016/j.cej.2008.08.014. 
Bhatnagar, A., Kumar, E., Sillanpää, M., 2011. Fluoride removal from water by adsorption - A review. Chem. Eng. J. 171, 811-840. https://doi.org/10.1016/j.cej.2011.05.028.

Chellam, S., Sari, M.A., 2016. Aluminum electrocoagulation as pretreatment during microfiltration of surface water containing NOM: A review of fouling, NOM, DBP, and virus control. J. Hazard. Mater. 304, 490-501. https://doi.org/10.1016/j.jhazmat.2015.10.054.

Chen, G., 2014. Electrochemical technologies in wastewater treatment. Sep. Purif. Technol. 38, 11-41. https://doi.org/10.1016/j.seppur.2003.10.006.

Chen, X., Chen, G., Yue, P.L., 2000. Separation of pollutants from restaurant wastewater by electrocoagulation. Sep. Purif. Technol. 19, 65-76. https://doi.org/10.1016/S1383-5866(99)000726.

Custodio, E., Cabrera, M.C., Poncela, R., Puga, L.-O., Skupien, E., del Villar, A., 2016. Groundwater intensive exploitation and mining in Gran Canaria and Tenerife, Canary Islands, Spain: Hydrogeological, environmental, economic and social aspects. Sci. Total Environ. 557558, 425-437. https://doi.org/10.1016/j.scitotenv.2016.03.038.

D’Alessandro, W., 2006. Human fluorosis related to volcanic activity: a review, Environmental Toxicology. WIT Trans. Biomed. Health. 10, 21-30. https://doi.org/10.2495/ETOX060031.

Drouiche, N., Aoudj, S., Lounici, H., Drouiche, M., Ouslimane, T., Ghaffour, N., 2012. Fluoride removal from pretreated photovoltaic wastewater by electrocoagulation: An investigation of the effect of operational parameters. Procedia Eng. 33, 385-391. https://doi.org/10.1016/j.proeng.2012.01.1218.

Dubrawski, K.L., Du, C., Mohseni, M., 2014. General potential-current model and validation for $\begin{array}{llll}\text { electrocoagulation. } & \text { Electrochim. } & \text { Acta } & 129,\end{array}$ https://doi.org/10.1016/j.electacta.2014.02.089.

Emamjomeh, M.M., Sivakumar, M., 2006. An empirical model for defluoridation by batch monopolar electrocoagulation/flotation (ECF) process. J. Hazard. Mater. 131, 118-125. https://doi.org/10.1016/j.jhazmat.2005.09.030.

Emamjomeh, M.M., Sivakumar, M., 2009. Fluoride removal by a continuous flow electrocoagulation reactor. J. Environ. Manage. 90, 1204-1212. https://doi.org/10.1016/j.jenvman.2008.06.001. 
EU Directive, EU Water framework directive. Available from: https://eur-lex.europa.eu/legalcontent/ES/TXT/?uri=uriserv:OJ.L_.2015.260.01.0006.01.SPA (retrieved 18.11.18).

Govindan, K., Raja, M., Uma Maheshwari, S., Noel, M., Oren, Y., 2015. Comparison and understanding of fluoride removal mechanism in $\mathrm{Ca}^{2+}, \mathrm{Mg}^{2+}$ and $\mathrm{Al}^{3+}$ ion assisted electrocoagulation process using Fe and Al electrodes. J. Environ. Chem. Eng. 3, 1784-1793. https://doi.org/10.1016/j.jece.2015.06.014.

Gürses, A., Yalçin, M., Doğar, C., 2002. Electrocoagulation of some reactive dyes; a statistical investigation of some electrochemical variable. Waste Manag. 22, 491-499. https://doi.org/10.1016/S0956-053X(02)00015-6.

Hakizimana, J.N., Gourich, B., Chafi, M., Stiriba, Y., Vial, C., Drogui, P., Naja, J., 2017. Electrocoagulation process in water treatment: A review of electrocoagulation modeling approaches. Desalination 404, 1-21. https://doi.org/10.1016/j.desal.2016.10.011.

Hardisson, A., Rodríguez, M.I., Burgos, A., Díaz Flores, L., Gutiérrez, R., Várela, H., 2001. Fluoride levels in publicly supplied and bottled drinking water in the Island of Tenerife, Spain. Bull. Environ. Contam. Toxicol. 67, 163-170. https://doi.org/10.1007/s001280106.

Hu, C.Y., Lo, S.L., Kuan, W.H., De Lee, Y., 2008, Treatment of high fluoride-content wastewater by continuous electrocoagulation-flotation system with bipolar aluminum electrodes. Sep. Purif. Technol. 60, 1-5. https://doi.org/10.1016/j.seppur.2007.07.040.

Jadhav, S.V., Bringas, E., Yadav, G.D., Rathod, V.K., Ortiz, I., Marathe, K.V., 2015. Arsenic and fluoride contaminated groundwaters: A review of current technologies for contaminants removal. J. Envirom. Manage. 162, 306-325. https://doi.org/10.1016/j.jenvman.2015.07.020.

Kanduti, D., Sterbenk, P., Artnik, B., 2016. Fluoride: A review of use and effects on health. Mater Sociomed. 28, 133-137. https://doi.org/10.5455/msm.2016.28.133-137.

Khaled, B., Wided, B., Béchir, H., Elimame, E., Mouna, L., Zied, T., 2014. Investigation of electrocoagulation reactor design parameters effect on the removal of cadmium from synthetic and phosphate industrial wastewater. Arab. J. Chem., In press, corrected proof, https://doi.org/10.1016/j.arabjc.2014.12.012. 
Khandegar, V., Saroha, A.K., 2013. Electrocoagulation for the treatment of textile industry effluent - A review. J. Environ. Manage. 128, 949-963. https://doi.org/10.1016/j.jenvman.2013.06.043.

Kobya, M., Can, O., Bayramoglu, M., 2003. Treatment of textile wastewater by electrocoagulation using iron and aluminum electrodes. J. Hazard. Mater. B100, 163-178. https://doi.org/10.1016/S0304-3894(03)00102-X.

Kobya, M., Can, O., Bayramoglu, M., Ulu, F., Oncel, S., Demirbas, E., 2011. Removal of arsenic from drinking water by the electrocoagulation using $\mathrm{Fe}$ and $\mathrm{Al}$ electrodes. Electrochim. Acta 56, 5060-5070. https://doi.org/10.1016/j.electacta.2011.03.086.

Kobya, M., Demirbas, E., Can, O., Bayramoglu, M., 2006. Treatment of levafix orange textile dye solution by electrocoagulation. J. Hazard. Mater. B132, 183-188. https://doi.org/10.1016/j.jhazmat.2005.07.084.

Krzeminski, P., Leverette, L., Malamis, S., Katsou, E., 2017. Membrane bioreactors - A review on recent developments in energy reduction, fouling control, novel configurations, LCA and market prospects. J. Membrane Sci. 527, 207-227. https://doi.org/10.1016/j.jmemsci.2016.12.010. Litter, M.I., Morgada, M.E., Bundschuh, J., 2010. Possible treatments for arsenic removal in Latin American waters for human consumption. Environ. Pollut. 158, 1105-1118. https://doi.org/10.1016/j.envpol.2010.01.028.

Martínez Vicente, D., 2002. Estudio de la Viabilidad Técnico-Económica de la Desalación de Agua de Mar por Osmosis Inversa en España (Study of the technical-economic viability of seawater desalination by reverse osmosis in Spain). Dissertation, Universidad de Murcia.

Mena, V.F., Betancor-Abreu, A., González, S., Delgado, S., Souto, R.M., Santana, J.J., Design and optimization of an electrocoagulation reactor for fluoride remediation in underground water sources for human consumption. Chem. Eng. J. submitted.

Mollah, M.Y.A., Morkovsky, P., Gomes, J.A., Kesmez, M., Parga, J., Cocke, D.L., 2004. Fundamentals, present and future perspectives of electrocoagulation. J. Hazard. Mater. 114, 199210. https://doi.org/10.1016/j.jhazmat.2004.08.009.

Ozsvath, D., 2008. Fluoride and environmental health: A review. Rev. Environ. Sci. Bio. 8 (1), 59-79. https://doi.org/10.1007/s11157-008-9136-9. 
Palahouane, B., Drouiche, N., Aoudj, S., Bensadok, K., 2015. Cost-effective electrocoagulation process for the remediation of fluoride from pretreated photovoltaic wastewater. J. Ind. Eng. Chem. 22, 127-131. https://doi.org/10.1016/j.jiec.2014.06.033.

Rajeshwar, K., Ibanez, J.G., Swain, G.M., 1994. Electrochemistry and the environment, J. Appl. Electrochem. 24, 1077-1091. https://doi.org/10.1007/BF00241305.

Rao, N., 2003. Fluoride and environment - a review, in: M.J. Bunch, V.M. Suresh, T.V. Kumaran (Eds.), Proceedings of the Third International Conference on Environment and Health, Chennai, India, pp. 386-399.

Real Decreto 140/2003, de 7 de febrero (BOE núm.45, de 21/02/2003). Available from: https://www.boe.es/buscar/act.php?id=BOE-A-2003-3596 (retrieved 18.11.18).

Rebhun, M., Lurie, M., 1993. Control of organic matter by coagulation and floc separation. Water Sci. Technol. 27, 1-20. https://doi.org/10.2166/wst.1993.0260.

Sepehri, A., Sarrafzadeh, M.-H., 2018. Effect of nitrifiers community on fouling mitigation and nitrification efficiency in a membrane bioreactor. Chem. Eng. Process. 128, 10-18. https://doi.org/10.1016/j.cep.2018.04.006.

Singh, J., Singh, P., Singh, A., 2016. Fluoride ions vs removal technologies: A study. Arab. J. Chem. 9, 815-824. https://doi.org/10.1016/j.arabjc.2014.06.005.

Sivakumar, M., Emamjomeh, M.M., 2005. Electrochemical method for fluoride removal: Measurement, speciation and mechanisms, in: N. Khanna (Eds.), Environmental Postgrad Conference; Environmental change: Making it Happen, Australia: School Civil \& Chemical Engineering, RMIT, Melbourne, pp. 1-8.

Tahaikt, M., Achary, I., Menkouchi Sahli, M.A., Amor, Z., Taky, M., Alami, A., Boughriba, A., Hafsi, M., Elmidaoui, A., 2006. Defluoridation of Moroccan groundwater by electrodialysis: Continuous operation. Desalination 189, 215-220. https://doi.org/10.1016/j.desal.2005.06.027.

Thakur, L.S., Mondal, P., 2017. Simultaneous arsenic and fluoride removal from synthetic and real groundwater by electrocoagulation process: Parametric and cost evaluation. J. Environ. Manage. 190, 102-112. https://doi.org/10.1016/j.jenvman.2016.12.053. 
Tian, Y., He, W., Zhu, X., Yang, W., Ren, N., Logan, B.E., 2016. Energy efficient electrocoagulation using an air-breathing cathode to remove nutrients from wastewater. Chem. Eng. J. 292, 308-314. https://doi.org/10.1016/j.cej.2016.02.004.

Wambu, E.W., Ambusso, W.O., Gerald, C.O., Muthakia, K., 2016. Review of fluoride removal from water by adsorption using soil adsorbents - An evaluation of the status. J. Water Reuse Desal. 6, 1-29. https://doi.org/10.2166/wrd.2015.073.

World Health Organization, 2001. Guidelines for Drinking-water Quality, 4th edn. Available from: https://www.who.int/water_sanitation_health/publications/drinking-water-quality-guidelines-4including-1st-addendum/en/ (retrieved 18.11.18).

Zhu, J., Zhao, H., Ni, J., 2007. Fluoride distribution in electrocoagulation defluoridation process. Sep. Purif. Technol. 56, 184-191. https://doi.org/10.1016/j.seppur.2007.01.030. 


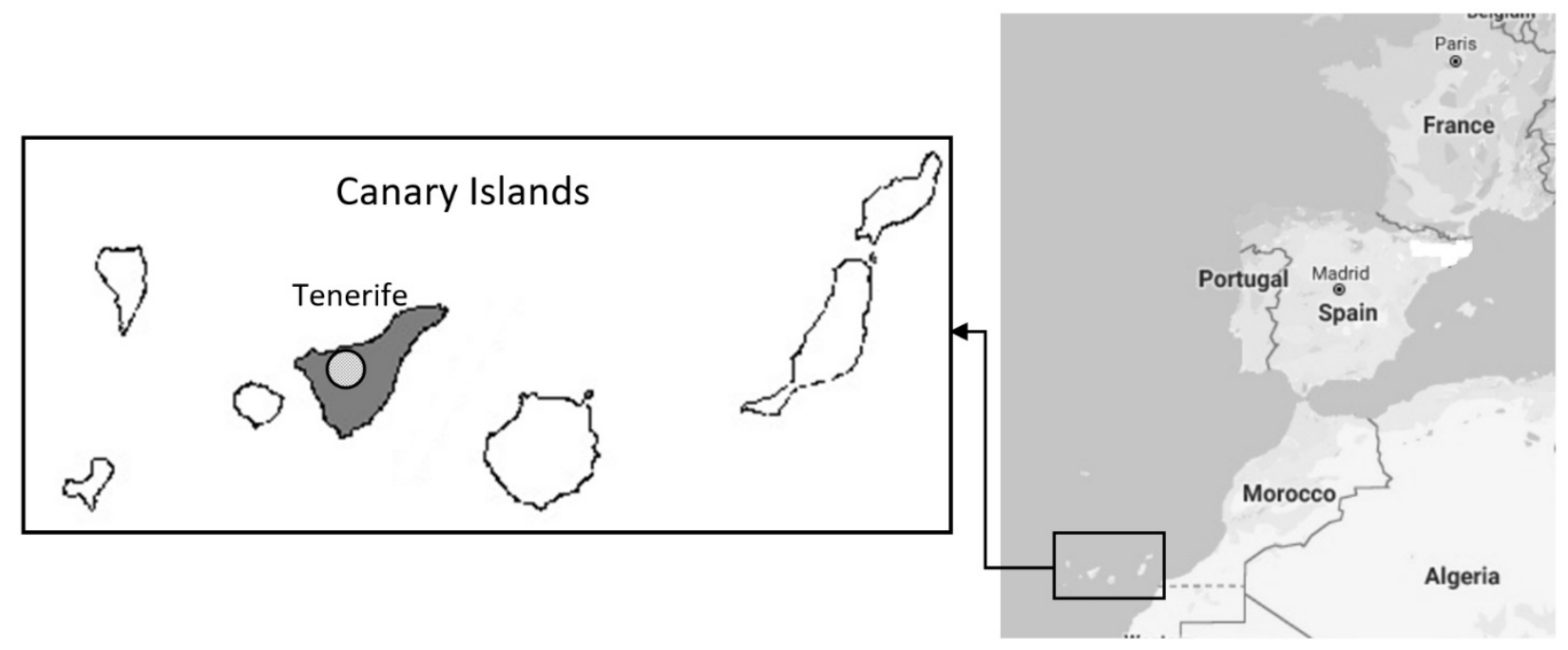

Figure 1. Location of the Canary Islands and the study area $(\otimes)$. 

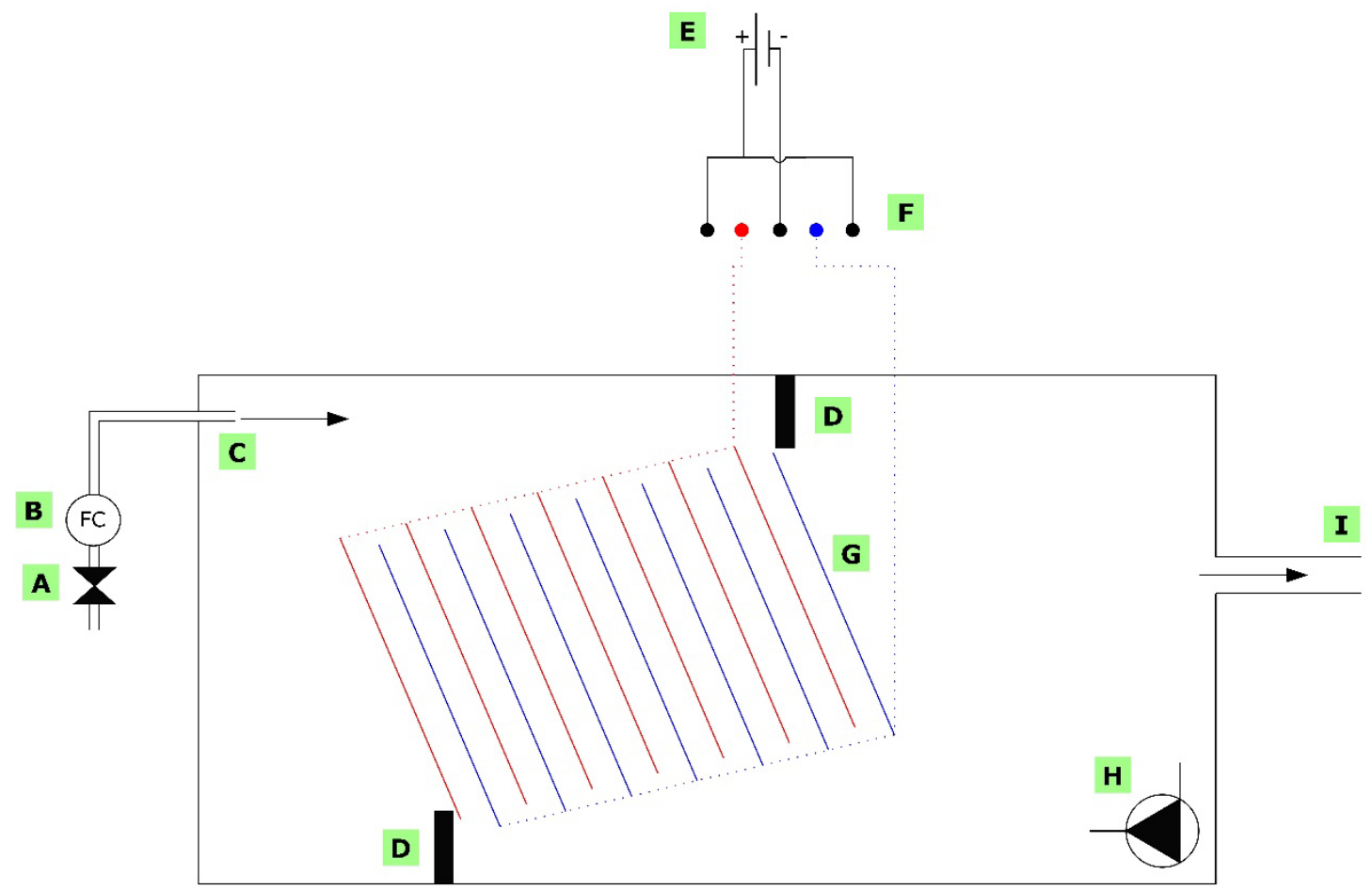
A Needle valve
D Flaps
G Electrodes
B Flowmeter
E Power supply
H Recirculating pump
C Raw water supply
F Switch
I Finished water

Figure 2. Sketch of the EC reactor employed in this work. 

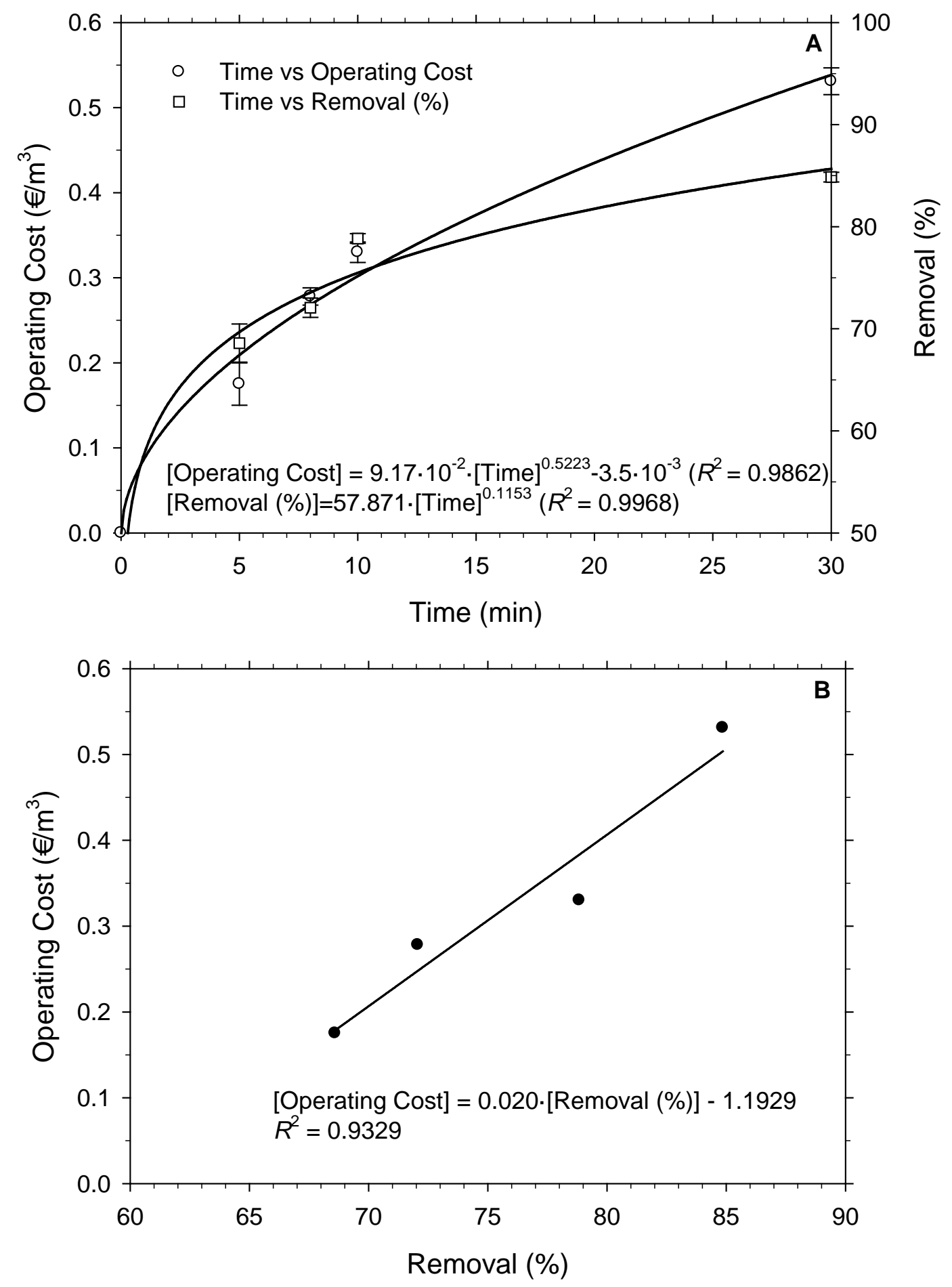

Figure 3. Performance of the EC reactor in batch operation: A) Evolution of the operating cost and percentage of fluoride removal; B) operating cost vs. fluoride removal. Operating conditions: initial $\mathrm{F}^{-}$concentration, $8.63 \mathrm{mg} / \mathrm{L}$; applied current density, $5 \mathrm{~mA} / \mathrm{cm}^{2}$; distance between the aluminum electrodes, $5 \mathrm{~mm}$. 


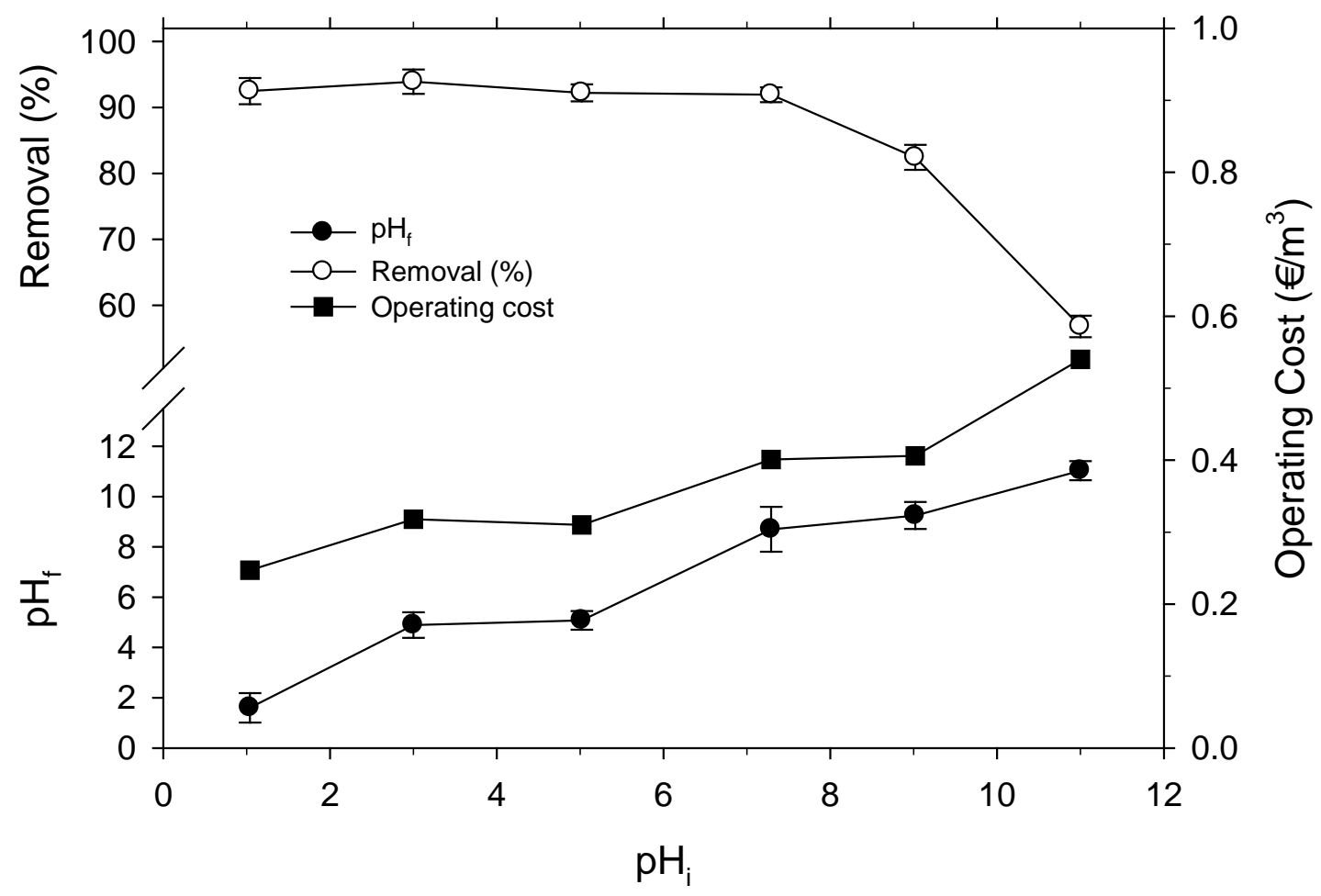

Figure 4. Influence of the initial $\mathrm{pH}$ of the raw water on the performance of the EC reactor in batch operation. Operating conditions: initial $\mathrm{F}^{-}$concentration, $7.06 \mathrm{mg} / \mathrm{L}$; applied current density, 10 $\mathrm{mA} / \mathrm{cm}^{2}$; run time, $30 \mathrm{~min}$; distance between the aluminum electrodes, $5 \mathrm{~mm}$. 


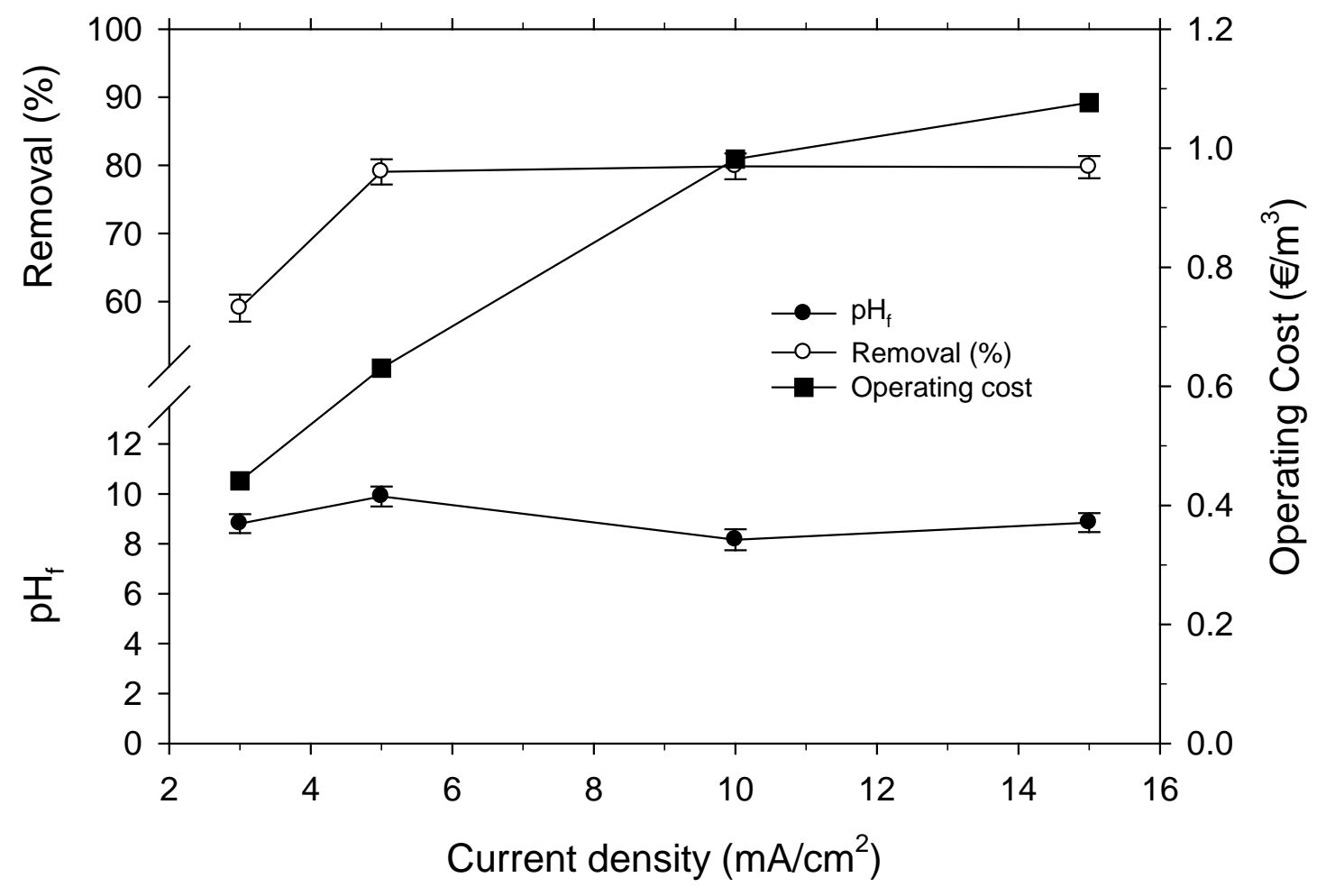

Figure 5. Influence of the applied current density on the performance of the EC reactor in batch operation. Operating conditions: initial $\mathrm{F}^{-}$concentration, $7.35 \mathrm{mg} / \mathrm{L}$; initial $\mathrm{pH}, 8.75$; run time, 30 min; distance between the aluminum electrodes, $5 \mathrm{~mm}$. 


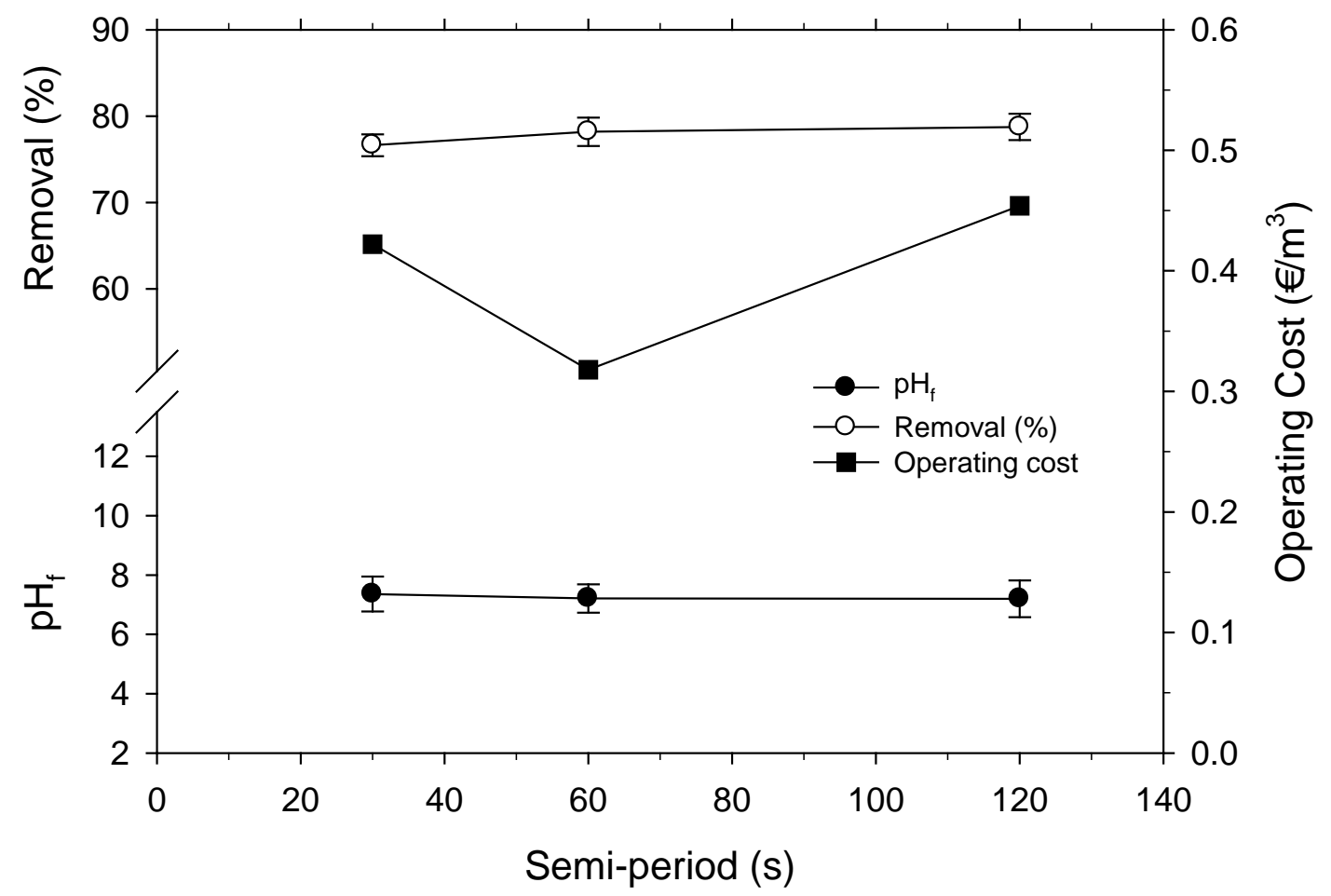

Figure 6. Influence of the voltage change semi-period on the performance of the EC reactor in batch operation. Operating conditions: initial $\mathrm{F}^{-}$concentration, $7.06 \mathrm{mg} / \mathrm{L}$; initial $\mathrm{pH}, 7.16$; run time, $600 \mathrm{~min}$; distance between the aluminum electrodes, $5 \mathrm{~mm}$. 

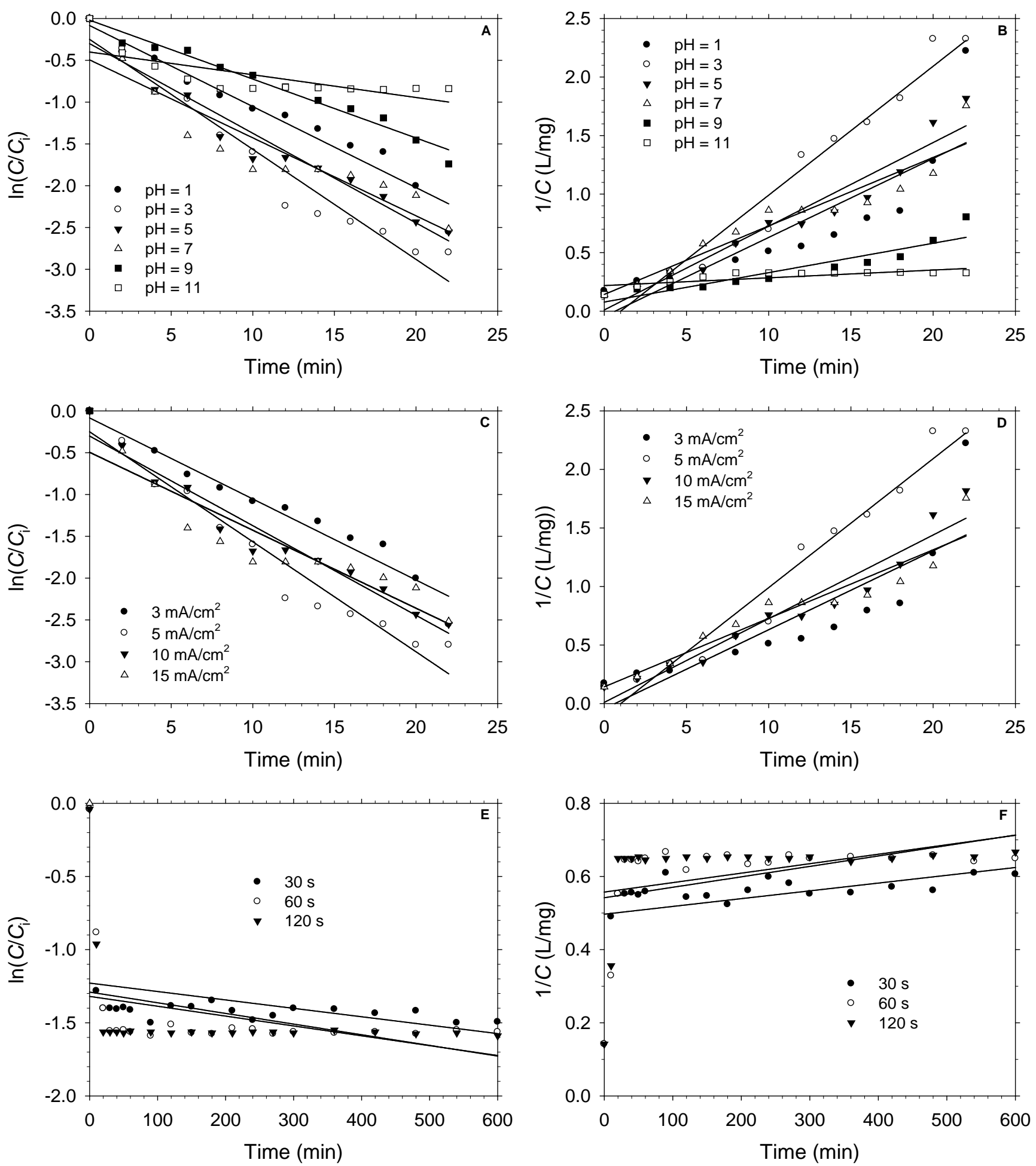

Figure 7.- Fits of the average experimental data from batch tests to (A,C,E) pseudo-first- and (B,D,F) pseudo-second-order kinetic models. Influences of: $(\mathrm{A}, \mathrm{B})$ the initial $\mathrm{pH} ;(\mathrm{B}, \mathrm{C})$ the applied current density; and (E,F) the voltage change semi-period. 


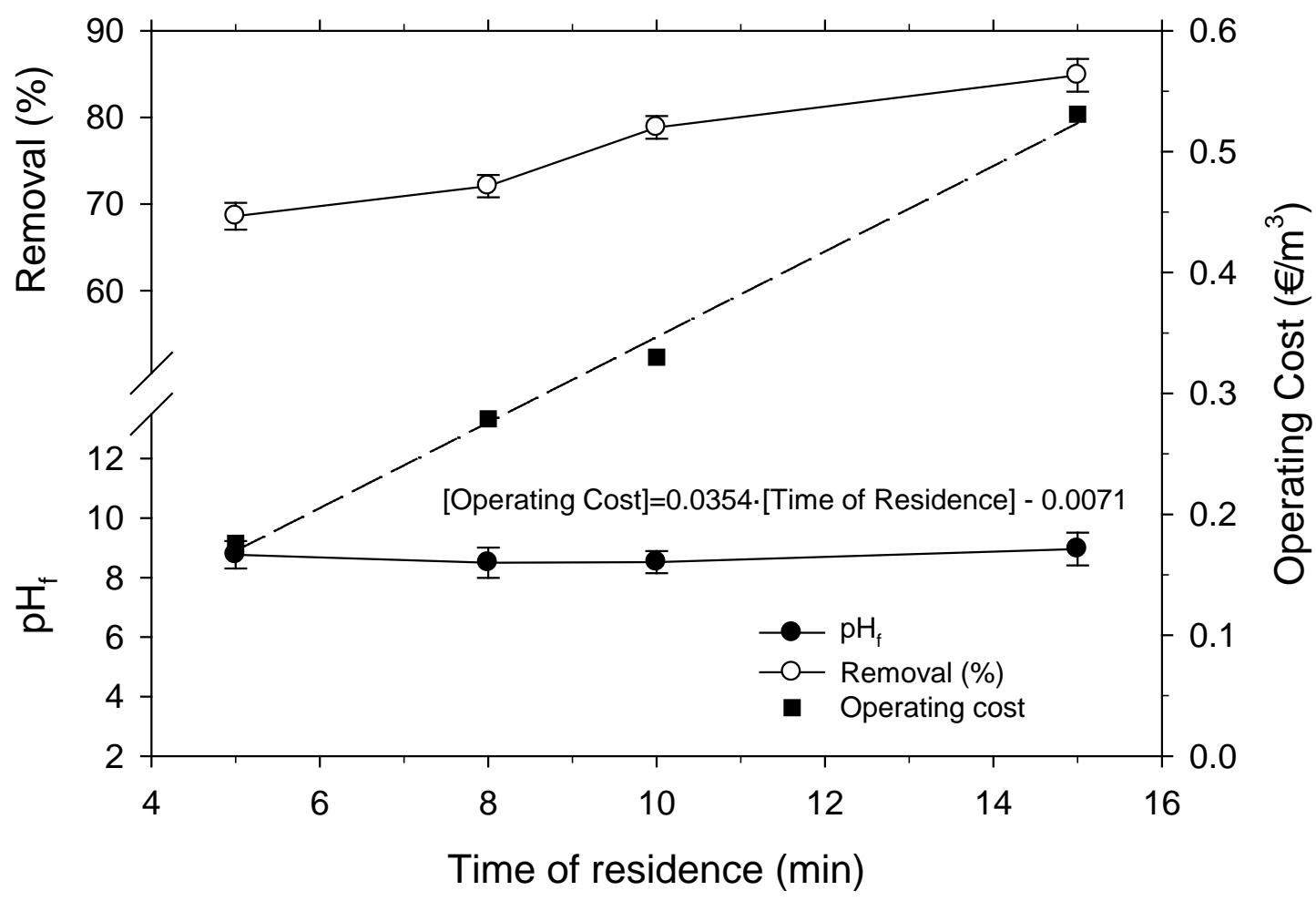

Figure 8. Influence of the time of residence on the performance of the EC reactor under continuous-flow regime. Operating conditions: initial $F^{-}$concentration, $8.63 \mathrm{mg} / \mathrm{L}$; initial $\mathrm{pH}, 7.30$; run time, $110 \mathrm{~min}$; distance between the aluminum electrodes, $5 \mathrm{~mm}$. 

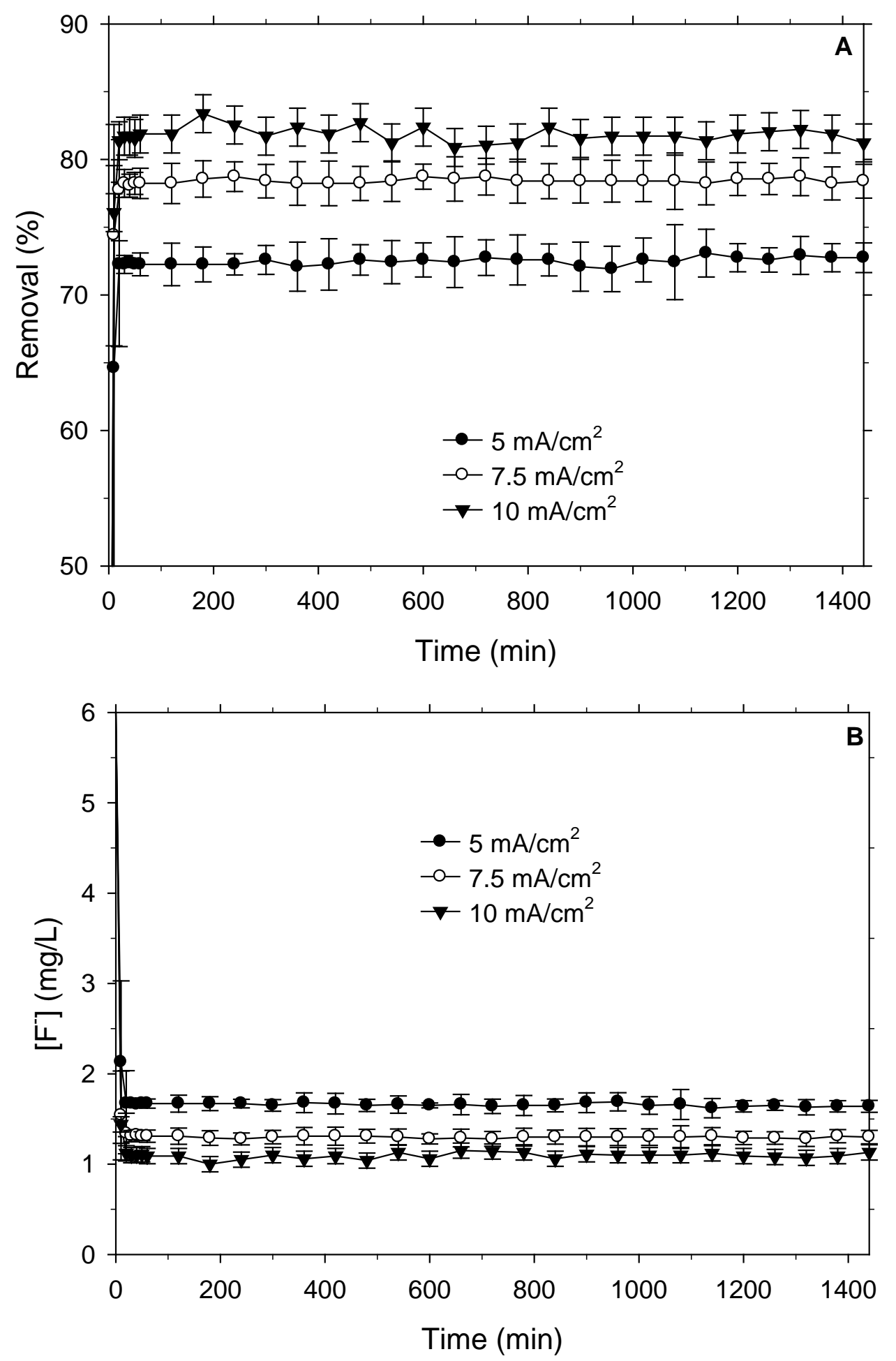

Figure 9. Performance of the EC reactor in continuous-flow operation for a water sample with $6.02 \mathrm{mg} / \mathrm{L}$ fluoride concentration at: (A) the beginning of the test, and (B) after $24 \mathrm{~h}$ operation. Operating conditions: initial $\mathrm{pH}, 8.41$; current density, $10 \mathrm{~mA} / \mathrm{cm}^{2}$; time of residence, $10 \mathrm{~min}$; distance between the aluminum electrodes, $5 \mathrm{~mm}$. 


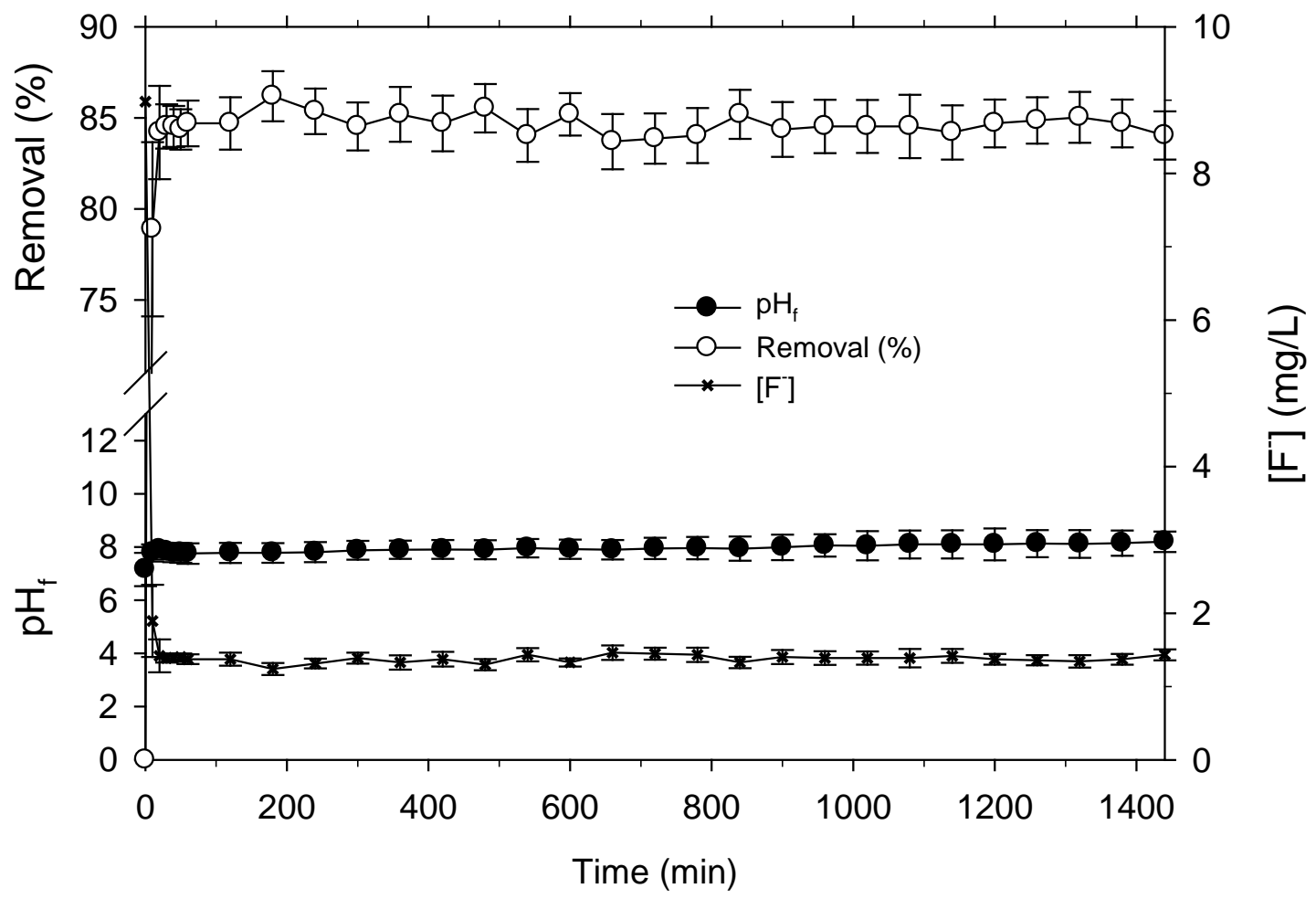

Figure 10. Performance of the EC reactor in continuous-flow operation for a water sample with $8.98 \mathrm{mg} / \mathrm{L}$ fluoride concentration after 24 h operation. Operating conditions: initial pH, 7.16; current density, $10 \mathrm{~mA} / \mathrm{cm}^{2}$; time of residence, $10 \mathrm{~min}$; distance between the aluminum electrodes, $5 \mathrm{~mm}$. 
Table 1. Classification of fluoride remediation technologies for water.

\begin{tabular}{|c|c|c|c|c|c|c|c|}
\hline Technique & References & Efficiency (\%) & Water loss (\%) & Load/dose & Cost & Strengths & Weeknesses \\
\hline & \multicolumn{7}{|c|}{ Methods based on precipitation processes } \\
\hline Aluminum & $\begin{array}{l}\text { (Ayoob et al., } \\
\text { 2008) }\end{array}$ & 90 & $1-2$ & 150 mg/(mg F-) & $\begin{array}{l}\text { Medium- } \\
\text { High }\end{array}$ & Established procedure & $\begin{array}{c}\text { Sludge formation } \\
\text { Acidic product water } \\
\text { Occurrence of residual } \mathrm{Al}^{3+}\end{array}$ \\
\hline Lime & $\begin{array}{l}\text { (Ayoob et al., } \\
\text { 2008) }\end{array}$ & $>90$ & $1-2$ & $30 \mathrm{mg}$ & $\begin{array}{l}\text { Medium- } \\
\text { High }\end{array}$ & Established procedure & $\begin{array}{l}\text { Sludge formation } \\
\text { Alkalinized product water }\end{array}$ \\
\hline Nalgonda & $\begin{array}{l}\text { Bhatnagar et al., } \\
2011\end{array}$ & $70-90$ & $1-2$ & - & $\begin{array}{l}\text { Medium- } \\
\text { High }\end{array}$ & Easiness of operation & High concentration of residual $\mathrm{Al}^{3+}(2-7 \mathrm{mg} / \mathrm{L})$ \\
\hline \multicolumn{8}{|c|}{ Methods based on adsorption and/or ionic exchange processes } \\
\hline $\begin{array}{l}\text { Activated } \\
\text { charcoal }\end{array}$ & \multirow{2}{*}{$\begin{array}{l}\text { (Ayoob et al., } \\
\text { 2008; Singh et } \\
\text { al., 2016) } \\
\text { (Bhatnagar et } \\
\text { al., 2011) }\end{array}$} & $>90$ & $1-2$ & Variable & High & $\begin{array}{l}\text { Adsorption load } 3-5 \text { times } \\
\text { greater than conventional } \\
\text { activated coal }\end{array}$ & pH change after treatment \\
\hline Charcoal & & 70 & $1-2$ & $300\left(\mathrm{mg} \mathrm{F}^{-}\right) / \mathrm{kg}$ & $\begin{array}{l}\text { Low- } \\
\text { Medium }\end{array}$ & Produced on site & Requires $\mathrm{KOH}$ \\
\hline Zeolite & \multirow{2}{*}{$\begin{array}{l}\text { (Wambu et al., } \\
\text { 2016) } \\
\text { (Ayoob et al., } \\
\text { 2008) }\end{array}$} & - & $1-2$ & $\begin{array}{c}0.36-0.54 \\
\mathrm{mg} /\left(\mathrm{g} \mathrm{F}^{-}\right)\end{array}$ & High & $\begin{array}{l}\text { Fluoride adsorption over a } \\
\text { wide range of water } \\
\text { conditions }\end{array}$ & Low capacity \\
\hline Ashes & & $60-70$ & $1-2$ & $80\left(\mathrm{mg} \mathrm{F}^{-}\right) / \mathrm{kg}$ & Low & Produced on site & $\begin{array}{l}\text { Low capacity } \\
\text { Show operation }\end{array}$ \\
\hline $\begin{array}{l}\text { Activated } \\
\text { alumina }\end{array}$ & \multirow{2}{*}{$\begin{array}{l}\text { (Rao, 2003) } \\
\text { (Jadhav et al., } \\
\text { 2015) }\end{array}$} & $85-95$ & $1-2$ & 800 mg/(mg F-) & Medium & $\begin{array}{c}\text { Good efficiency } \\
\text { Removal of As } \\
\text { Low energy consumption }\end{array}$ & $\begin{array}{l}\text { Interference by hardness, silica and boron, etc. } \\
\text { Big influence of } \mathrm{pH} \text { on efficiency, thus requiring } \\
\text { pH adjustment }\end{array}$ \\
\hline Bones & & Low & $1-2$ & $900\left(\mathrm{mg} \mathrm{F}^{-}\right) / \mathrm{m}^{3}$ & Low & Produced on site & Better for the removal of $F$ than As \\
\hline & \multicolumn{7}{|c|}{ Methods based on membrane operation } \\
\hline Electrodyalisis & $\begin{array}{l}\text { (Tahaikt et al., } \\
\text { 2015) }\end{array}$ & $85-95 \%$ & $20-30$ & High & $\begin{array}{l}\text { Very } \\
\text { high }\end{array}$ & $\begin{array}{l}\text { Higher efficiencies than } \\
\text { other membrana-based } \\
\text { techniques } \\
\text { Flexibility to deal with } \\
\text { seaonal variability in the } \\
\text { raw waters }\end{array}$ & $\begin{array}{l}\text { High water losses } \\
\text { High energy consumption }\end{array}$ \\
\hline $\begin{array}{l}\text { Reverse } \\
\text { osmosis }\end{array}$ & $\begin{array}{l}\text { (Jadhav et al., } \\
\text { 2015; Litter et } \\
\text { al., 2010)) }\end{array}$ & $76-95 \%$ & $40-60$ & High & $\begin{array}{l}\text { Very } \\
\text { high }\end{array}$ & Removal of As & $\begin{array}{c}\text { Small water recovery ratios (typically 10-20\%) } \\
\text { High energy consumption }\end{array}$ \\
\hline
\end{tabular}


Table 2. Experimental conditions of the electrocoagulation operation.

\begin{tabular}{cc}
\hline Parameter & Variability range \\
\hline Current density $\left(\mathrm{mA} / \mathrm{cm}^{2}\right)$ & $3-15$ \\
Half-period of polarity change $(\mathrm{s})$ & $30-120$ \\
Distance between the electrodes $(\mathrm{cm})$ & 0.5 \\
Initial $\mathrm{pH}$ & $1.04-11.20$ \\
Initial $\left[\mathrm{F}^{-}\right](\mathrm{mg} / \mathrm{L})$ & $6.02-8.98$ \\
$\Delta V(\mathrm{~V})$ & $0.73-24.20$ \\
\hline
\end{tabular}

Table 3. Average chemical composition of the raw water.

\begin{tabular}{|c|c|c|c|c|c|}
\hline \multicolumn{3}{|c|}{ Cations } & \multicolumn{3}{|c|}{ Anions } \\
\hline & $\mathrm{meq} / \mathrm{L}$ & $\mathrm{mg} / \mathrm{L}$ & & $\mathrm{meq} / \mathrm{L}$ & $\mathrm{mg} / \mathrm{L}$ \\
\hline Calcium & 0.99 & 19.80 & Carbonate & 0.00 & $<0.25$ \\
\hline Magnesium & 5.89 & 71.60 & Bicarbonate & 23.80 & 1453 \\
\hline Potasium & 2.21 & 86.40 & Sulfate & 1.00 & 48 \\
\hline Sodium & 17.40 & 401 & Chloride & 0.62 & 22 \\
\hline Aluminum & & $<0.01$ & Nitrate & 0.08 & 5.2 \\
\hline & & 7.2 & Nitrite & 0.00 & $<0.1$ \\
\hline \multirow{2}{*}{\multicolumn{2}{|c|}{ Conductivity (mS/cm @ 25ㄷ) }} & 2140 & Phosphate & 0.03 & 1.0 \\
\hline & & & Fluoride & 0.43 & 8.1 \\
\hline
\end{tabular}

Table 4. Performance of the EC reactor in batch operation. Operation conditions of the EC reactor: initial $\mathrm{pH}$, 9.14; current density, $5 \mathrm{~mA} / \mathrm{cm}^{2}$; distance between the electrodes, $5 \mathrm{~mm}$.

\begin{tabular}{cccccc}
\hline $\boldsymbol{t}(\mathbf{m i n})$ & {$\left[\mathbf{F}^{-}\right]_{\mathbf{i}}$} & {$\left[_{\mathbf{F}}^{-}\right]_{\mathbf{f}}$} & $\begin{array}{c}\text { Removal } \\
(\mathbf{\%})\end{array}$ & $\begin{array}{c}\text { Voltage drop } \\
(\mathbf{V})\end{array}$ & Operating Cost $\left(\boldsymbol{€} / \mathbf{m}^{\mathbf{3}}\right)$ \\
\hline 5 & 8.63 & 2.71 & 68.60 & 0.5 & 0.175 \\
8 & 8.63 & 2.41 & 72.07 & 0.8 & 0.278 \\
10 & 8.63 & 1.9 & 78.84 & 1 & 0.330 \\
30 & 8.63 & 1.36 & 84.86 & 1.2 & 0.531 \\
\hline
\end{tabular}


Table 5. Influence of initial water $\mathrm{pH}$ on the electrocoagulation process in batch regime. Operation conditions of the EC reactor: current density, $5 \mathrm{~mA} / \mathrm{cm}^{2}$; distance between the electrodes, $5 \mathrm{~mm}$.

\begin{tabular}{ccccccc}
\hline $\mathbf{p H}_{\mathbf{i}}$ & $\mathbf{p H}_{\mathbf{f}}$ & $\begin{array}{c}{\left[\mathbf{F}^{-}\right]_{\mathbf{i}}} \\
(\mathbf{m g} / \mathbf{L})\end{array}$ & $\begin{array}{c}\left.\mathbf{F}^{-}\right]_{\mathbf{f}} \\
(\mathbf{m g} / \mathbf{L})\end{array}$ & $\begin{array}{c}\text { Removal } \\
(\mathbf{\%})\end{array}$ & $\begin{array}{c}\text { Voltage } \\
\text { drop }(\mathbf{V})\end{array}$ & $\begin{array}{c}\text { Operating } \\
\text { Cost }\left(\mathbf{\epsilon} / \mathbf{m}^{\mathbf{3}}\right)\end{array}$ \\
\hline 1.04 & 1.72 & 7.06 & 0.53 & 92.49 & 1.34 & 0.247 \\
3.00 & 4.89 & 7.06 & 0.43 & 93.91 & 2.13 & 0.318 \\
5.02 & 5.08 & 7.06 & 0.55 & 92.21 & 2.04 & 0.310 \\
7.29 & 8.94 & 7.06 & 0.57 & 91.93 & 3.05 & 0.401 \\
9.02 & 9.25 & 7.06 & 1.24 & 82.44 & 3.11 & 0.406 \\
11.00 & 11.03 & 7.06 & 3.05 & 56.80 & 4.59 & 0.540 \\
\hline
\end{tabular}

Table 6. Influence of initial $\mathrm{pH}$ and applied current density on the EC operation assuming pseudo first- and second-order kinetics. Operation conditions of the EC reactor: Operating time, $30 \mathrm{~min}$; Current density, $5 \mathrm{~mA} / \mathrm{cm}^{2}$; distance between the electrodes, $5 \mathrm{~mm}$.

\begin{tabular}{cccccc}
\hline \multirow{2}{*}{ Parameter } & \multirow{2}{*}{ Value } & \multicolumn{2}{c}{ Pseudo first-order } & \multicolumn{2}{c}{ Pseudo second-order } \\
\cline { 2 - 5 } & & $\boldsymbol{k}_{\mathbf{1}}\left(\mathbf{\times 1 \mathbf { 1 0 } ^ { 2 } )}\right.$ & $\boldsymbol{R}^{\mathbf{2}}$ & $\boldsymbol{k}_{\mathbf{2}} \mathbf{( \times \mathbf { 1 0 } ^ { \mathbf { 2 } } )}$ & $\boldsymbol{R}^{\mathbf{2}}$ \\
\hline Raw water & $30 \mathrm{~min}$ & 4.30 & 0.9850 & 0.940 & 0.9883 \\
\hline & 1 & 9.69 & 0.9579 & 6.75 & 0.7276 \\
$\mathrm{pH}$ & 3 & 13.16 & 0.9535 & 11.0 & 0.9581 \\
& 5 & 10.72 & 0.9553 & 7.15 & 0.9353 \\
& 7 & 9.33 & 0.8625 & 5.86 & 0.9023 \\
& 9 & 7.05 & 0.9751 & 2.51 & 0.8618 \\
& 11 & 2.72 & 0.5706 & 6.60 & 0.6255 \\
\hline \multirow{2}{*}{ Current density } & 3 & 4.09 & 0.9653 & 9.20 & 0.9874 \\
$\left(\mathrm{~mA} / \mathrm{cm}^{2}\right)$ & 5 & 6.47 & 0.9185 & 2.35 & 0.9779 \\
& 10 & 6.74 & 0.8242 & 2.63 & 0.8960 \\
& 15 & 6.70 & 0.8786 & 2.56 & 0.9514 \\
\hline
\end{tabular}

Table 7.- Compliance of the product water to the legal requirements.

\begin{tabular}{lccc}
\hline \multirow{2}{*}{ Parameters } & \multirow{2}{*}{ Legal requirement } & \multicolumn{2}{c}{ Average values in the product water } \\
{$\left[\mathbf{F}^{-}\right]_{\mathbf{i}}=\mathbf{6 . 0 2} \mathbf{~ m g} / \mathbf{L}$} & {$\left[\mathbf{F}^{-}\right]_{\mathbf{i}}=\mathbf{8 . 9 8} \mathbf{~ m g} / \mathbf{L}$} \\
\hline Current density & - & $7.5 \mathrm{~mA} / \mathrm{cm}^{2}$ & $10 \mathrm{~mA} / \mathrm{cm}^{2}$ \\
Fluoride & $1.5 \mathrm{mg} / \mathrm{L}$ & $2.2 \mathrm{mg} / \mathrm{L}$ & $1.30 \mathrm{mg} / \mathrm{L}$ \\
Aluminum & $200 \mu \mathrm{g} / \mathrm{L}$ & $50 \mu \mathrm{g} / \mathrm{L}$ & $50 \mu \mathrm{g} / \mathrm{L}$ \\
$\mathrm{pH}$ & $6.5-9.5$ & 9.10 & 8.20 \\
\hline
\end{tabular}

